\title{
Approaches to Assessing the Strategic Sustainability of High-Risk Offshore Oil and Gas Projects
}

\author{
Alexey Cherepovitsyn ${ }^{1}$, Anna Tsvetkova ${ }^{1}$ and Nadejda Komendantova ${ }^{2, *}$ \\ 1 Department of Organization and Management, Saint Petersburg Mining University, 2, 21st Line, \\ 199106 Saint Petersburg, Russia; Cherepovitsyn_AE@pers.spmi.ru (A.C.); Tsvetkova_AYu@pers.spmi.ru (A.T.) \\ 2 International Institute for Applied Systems Analysis (IIASA), Schlossplatz 1, A-2361 Laxenburg, Austria \\ * Correspondence: komendan@iiasa.ac.at
}

Received: 25 November 2020; Accepted: 4 December 2020; Published: 6 December 2020

\begin{abstract}
In the face of today's global challenges, oil and gas companies must define long-term priorities and opportunities in implementing complex Arctic offshore projects, taking into account environmental, economic, technological and social aspects. In this regard, ensuring strategic sustainability is the basis for long-term development. The aim of the study is to analyze existing approaches to the concept of "strategic sustainability" of an offshore Arctic oil and gas project and to develop a methodological approach to assessing the strategic sustainability of offshore oil and gas projects. In the theoretical part of the study, the approaches to defining strategic sustainability were reviewed, and their classification was completed, and the most appropriate definition of strategic sustainability for an offshore oil and gas project was chosen. The method of hierarchy analysis was used for strategic sustainability assessment. Specific criteria have been proposed to reflect the technical, geological, investment, social and environmental characteristics important to the offshore oil and gas project. The strategic sustainability of 5 offshore oil and gas projects was analyzed using an expert survey as part of the hierarchy analysis method. Recommendations were made on the development of an offshore project management system to facilitate the emergence of new criteria and improve the quality of the strategic sustainability assessment of offshore projects in the Arctic.
\end{abstract}

Keywords: offshore; Arctic; hydrocarbon resources; oil and gas projects; strategic sustainability; investment; technological; geological; environmental and social criteria

\section{Introduction}

Over the last decade, the global trend in the majority of oil and gas producing countries has been to reduce oil and gas production in traditional oil and gas production centers. At the same time, the Arctic continental shelf is one of the most attractive and promising areas in terms of hydrocarbon resource potential. According to preliminary estimates, up to $25 \%$ of the world's hydrocarbon reserves are concentrated in the Arctic, guaranteeing energy security for many European countries and the world for decades to come [1]. The estimated hydrocarbon potential of the Russian Arctic shelf for recoverable reserves is 9579.3 million tons of fuel equivalent [2,3]. For many decades, Russia has been actively developing the mineral and raw material potential of the Arctic $[4,5]$.

The Russian Federation is one of the largest exporters of fuel and energy raw materials under the existing international division of labor system. The competitive advantage achieved in Russia's oil and gas sector on the global energy market can ensure the stable development of the national economy and social sphere and the formation and replenishment of budgets at all levels. Russia's Energy Strategy for the period until 2035 determines the need to bring annual oil production to 490-550 million tons. Achievement of the planned production levels is possible with oil reserves replacement in the amount of more than 13-15 billion tons [6]. 
Many specialists and experts believe that the key strategic objective for the long-term sustainable development of the oil and gas industry is the balanced development of the Arctic hydrocarbon potential, including, above all, the environmentally safe development of offshore fields [7-11]. The government and operators of Arctic oil and gas projects are faced with new organizational and managerial tasks, the solution of which will improve the sustainability of offshore hydrocarbon development in the Arctic shelf, ensuring the economic efficiency of all project participants, taking into account social factors in the development of Arctic territories, the environmental balance and technological development [12-16].

For the successful development and sustainable functioning of the oil and gas industry in the Arctic zone, a set of tasks must be successfully completed, which include scientific, technological, infrastructural, social and investment attraction tasks in this sector. Difficult climatic conditions, high capital intensity, irreversible technological and managerial mistakes that lead to environmental disasters highlight the high risks of offshore oil and gas projects. It is also necessary to take into account the long-term nature of such projects and their strategic orientation, i.e., such projects require serious costs and involve irreversible management decisions in the areas of economics, technology and logistics, together with constantly arising geopolitical factors [17-19]. The assessment of offshore Arctic oil and gas projects in Russia practically does not take into account the carbon intensity factor of newly established production facilities. Global low-carbon development trends and the fight against anthropogenic $\mathrm{CO}_{2}$ emissions $[20,21]$, along with the growing share of renewable energy and the global players' plans to reduce oil production on the world energy market, are precisely the challenges that Russian companies' management must take into account when determining the prospects for developing the Arctic shelf.

The authors of this study, however, believe that the development of Arctic marine hydrocarbon resources is a major challenge that threatens natural systems. It may be better to develop fields on land and to increase the oil supply of old fields, where technologies have been tested, including those for environmental protection. However, if the company begins to implement offshore projects in the Arctic, environmental and safety issues will be fundamental. The start of such projects must therefore be accompanied by a detailed sustainability assessment, with priority consideration of the environmental factor and of all impacts on local communities.

Ensuring the strategic sustainability of oil and gas projects is directly linked to the specifics of the oil and gas industry, particularly offshore oil and gas production in the Arctic, and to global processes, particularly the consequences of the pandemic and the ability of oil and gas companies to develop in the post-pandemic period.

The profitability of oil and gas production is determined by fluctuating demand in global markets, which in turn are affected by the global coronavirus pandemic crisis. A significant drop in global hydrocarbon prices due to a fall in global production during the pandemic, increased use of alternative energy sources and opportunities to increase unconventional hydrocarbon production may lead to the freezing of investment activities and the closure or indefinite postponement of oil and gas projects [22,23].

Given the high volatility of oil prices and the loss of profit for oil and gas companies, as well as government revenues, there may be a serious decline in exploration work aimed at increasing hydrocarbon reserves. In other words, the industry may remain with a low oil and gas reserve replacement rate [23].

Most of the Russia's new fields (Arctic shelf, Eastern Siberia, Far East) are located far away from transport and port infrastructure and consumers, so the profitability of their production, especially with small reserves, can be marginal to profitability or negative. However, oil in new fields often has the worst chemical composition, particularly in terms of sulfur content and density. The decline in the quality of the resource base is a major challenge for the Russian oil and gas sector and its sustainable development, along with the coronavirus pandemic and EU and US sanctions [23].

In connection with the above, the authors of the article can state that approaches to assessing the strategic sustainability of high-risk Arctic oil and gas projects are a relevant area of study. 
The purpose of the study is to analyze the existing approaches to the concept of "strategic sustainability" of an offshore Arctic oil and gas project and to identify a set of indicators required for strategic sustainability assessment, as well as to propose a methodological approach to assessing the strategic sustainability of offshore oil and gas projects and provide recommendations on the development of a strategic sustainability assessment system for offshore oil and gas projects.

The following research questions are raised in the article:

- What is meant by the strategic sustainability of an offshore oil and gas project in the Arctic?

- What are the criteria for assessing offshore oil and gas projects, taking into account their specific features, global energy sector trends and the risks associated with these projects?

- What can be suggested to improve the strategic sustainability assessment of an offshore oil and gas project?

The structure of the article is the following:

- Study of theoretical approaches to determining the sustainability and strategic sustainability of complex industrial systems and offshore oil and gas projects;

- Identification of key risks in offshore projects;

- Identification of specific criteria for assessing the strategic sustainability of the offshore oil and gas project;

- Identification of suitable methodological tools for assessing the strategic sustainability of offshore oil and gas projects in the Arctic;

- Assessing the strategic sustainability of existing offshore projects in the Russian Arctic shelf using expert surveys;

- Recommendations on developing a system of strategic sustainability assessment indicators.

Therefore, first, we would like to look at existing theoretical approaches to defining the strategic sustainability of offshore oil and gas projects in the Arctic.

\section{The Problem of Strategic Sustainability of Offshore Oil and Gas Projects in the Arctic}

Despite an extensive list of studies on the strategic sustainability of industrial systems and projects, there is currently no generally accepted methodology for assessing it. This is particularly true for Arctic oil and gas development projects, which are highly risky and have a strong specific nature. In general, a project is a set of processes aimed at creating a unique product, service or result that meets specific requirements defined in advance, including time, cost and scope limits [24-27]. The Offshore Oil and Gas Project is the creation of a unique industrial system for the production of hydrocarbons within a certain budget in order to achieve the planned result.

In oil and gas companies, projects are usually divided into two categories: investment projects-projects that involve capital expenditure for the purpose of making a profit and/or achieving other beneficial effects; operational projects—other projects involving non-capital expenditure.

Project management is an important process that ensures the reasonable and efficient use of funds, including investment resources, for the development of enterprises in accordance with their strategic and annual plans. Project management is linked to the strategy, accompanied by a stated mission and vision, as well as strategic goals and objectives, in order to balance the use of resources in carrying out strategic and operational activities. That is, any oil and gas project, in addition to economic (financial) sustainability, must also have strategic sustainability.

The concept of sustainability is not uniquely defined because it is widely used in different areas with different meanings and implications.

\subsection{Definition of Sustainability}

Let us consider the approaches of various authors to the definition of sustainability at the project level (business entity). 
According to Teplova [28], "sustainability of an investment project is a characteristic of a project that shows that it remains effective when the conditions for its implementation change".

The Big Economic Dictionary, edited by Azriliyan, A.N. [29], gives the following definition: "sustainability is firmness, constancy and not subject to the risk of loss or damage".

According to Lopatnikov [30] he stability of a system is the ability of a dynamic system to maintain movements along its intended trajectory (maintain its intended mode of operation) despite disturbances affecting it.

According to Altshuler [31] sustainability is a constant response to changes in the external environment, provided that the company's income and output are managed in line with market requirements.

Finally, Manitskaya, L.N. in her work [32] declares that sustainability is the ability of the system to function effectively in the face of external influences and internal disturbances.

As we can see, a common concept in the authors' definitions of "project sustainability" is the ability of a project to function effectively in a fluid environment with high uncertainty and to return to a balanced state more quickly. Such definitions are more suited to the concept of sustainability. In our study, we do not consider it appropriate to use these definitions, which are only partially appropriate for oil and gas projects. The above definitions do not reflect the specifics of offshore oil and gas projects where companies operate in a fragile environment, global trends in the need to combat greenhouse gas emissions and high social responsibility.

It is very important to clearly identify the definitions of "sustainability" in the global context, because this context reflects the need to assess the sustainability of the offshore oil and gas project from a social and environmental perspective. A large number of definitions were proposed after the well-known Brundtland report "Our Common Future" was published [33]. The main idea of sustainable development outlined in this report is that our planet's resources are limited and that, given current consumption patterns, there are a number of risks and disasters ahead of us that are linked to the negligence of people towards our planet. Sustainability generally refers to economic, environmental or social sustainability [34]. On the contrary, development without environmental, social and economic sustainability will lead to a collapse of the economy, society and the environment [35].

Economic sustainability refers mainly to economic growth and the various practices that support it in the long term. The quantitative definition of economic sustainability refers only to economic growth, which is defined as the ability of an economy to maintain a certain level of economic production. In this case, sustainable development is confused with economic growth [36]. An increasing number of scientists are now expressing concern that current economic growth can no longer be sustained without damaging our planet [37]. Economic growth cannot be sustainable if natural resources are used without restrictions or if society continues to depend on economic activities such as the extraction of natural resources, which were the driving force behind economic growth in the past [38]. There are also more complete definitions of economic sustainability. For example, such definitions include qualitative growth that is not associated with increased consumption of natural resources. The concept of fair economic sustainability speaks to the fair distribution of the benefits of economic growth in society [39].

Environmental sustainability is defined as respect for nature in order to conserve natural resources and avoid deterioration of soil, air, water, biodiversity, etc. According to the environmental component of sustainable development, the needs of the present generation must be met without compromising the needs of the future generation, which means that future generations will have the same quality of water, air, soil and biological diversity. The term "environmental sustainability" is closely linked to the term "sustainability", which sees the entire earth as a system that must preserve its integrity and return to a state of equilibrium after various shocks [40]. The goal of environmental sustainability is to maintain the balance of our planet within its boundaries, such as climate change, biodiversity loss or changes in the global nitrogen cycle [41]. The issues of climate change and $\mathrm{CO}_{2}$ mitigation options are of great importance, and it must be assumed that global processes in the global economy dictate 
the need to increase energy efficiency in all sectors, to replace coal and oil generation with natural gas; to actively use solar, wind, geothermal and hydro power and to introduce $\mathrm{CO}_{2}$ sequestration technologies on a large scale. Of course, in order to assess strategic sustainability, it is advisable to take into account the challenges for conventional energy (fossil fuels) that exist in the context of society's struggle against global climate change [42,43].

The existing definition of environmental sustainability is closely linked to Environmental Impact Assessment (EIA), which is one of the tools for implementing environmental sustainability. The purpose of the EIA is to reduce or prevent negative environmental impacts of infrastructure projects, including oil and gas projects [44]. When planning infrastructure projects in the Arctic, the purpose of the EIA procedures is to protect the fragile nature of the Arctic region, which is also a habitat for indigenous peoples in the region [45]. For example, reindeer husbandry is one of the most important indigenous and traditional livelihoods in the circumpolar Arctic and the Barents region [46], and this depends to a large extent on the well-being of the environment. The purpose of the EIA is therefore not only to protect the environment but also to reduce the risks associated with the development of industrial infrastructure, such as the development of an oil and gas field in the Arctic and changes in land use $[47,48]$.

Existing definitions of social sustainability are linked to the impact that policies or infrastructure projects have on the local community, in the regions where the projects are planned. Social sustainability is not always given the right emphasis in the context of sustainable development [49]. In addition, social sustainability was often given the lowest priority in international policy development or major international projects [50]. More and more attention is now being paid to this term. The development of projects contributes to the growth of jobs, the professional skills of employees and their competences. In addition, the social aspect of sustainability is expressed through the inclusion of public opinion in the implementation of major industrial and infrastructure projects, including projects related to the development of hydrocarbon deposits, and the need to combat public protests, as well as the development of policy decisions on the construction of industrial facilities and infrastructure that are based on principles of fairness. Equity principles include such factors as the distribution of the results of decision-making processes and procedural fairness, which means how different social groups are involved in decision-making processes. In response to this need, a number of international organizations have developed social impact assessment (SIA) procedures [51,52]. SIAs were first introduced in the US and then widely implemented in a number of other regions and countries with multilateral donor organizations such as the World Bank [53], which plays an important role in their implementation [54]. This understanding of social sustainability goes beyond the so-called "not in my backyard yard" concept. (NIMBY) or various types of "decide-announce-defend" models $[55,56]$.

The concept of social justice and social equity was frequently discussed in various scientific works. It was also described as social, distributive or output justice; fairness over distribution and access to resources or equality in various conditions which are important for the modern lifestyle. It also frequently related to social inclusion and access to key services and facilities [57]. Most frequently, the concept of socially just or equitable development was discussed in relation to urban growth, considering the growing number of inhabitants in the cities and the speed of urbanization processes in various parts of the world. The concept of socially just urban development was introduced by Campbell in 1996 [58]. It meant development which shall address three major existing conflicts between economic growth, fair distribution of the results of this growth and protection of environment with presentation of nature resources. The author introduced a triangle, which should serve as a recommendation for policy planners to solve the first conflict between economic growth and equity, then the resource conflict and, further on, the development conflict. Participatory governance and engagement of various stakeholders on discussion of possible ways and solutions between these three conflicts was identified as an option for compromised oriented sustainable development.

The social justice principles were further applied to other policies domains. Jenkins et al. [59] suggested to apply these principles in regard to energy policy. According to Jenkins et al. [59], 
energy justice should evaluate areas where injustices occur, it should show which parts of society are ignored, it should analyze which processes exist for remediation and further on propose measures to reduce these injustices. The preliminary concern of the just and fair energy policy should be how to distribute benefits and burdens of various energy systems.

Until recently, energy policy was mainly concerned with energy systems and discussion about their effectiveness and efficiency. Now, the scientific discussion moves stronger to the direction of distributional, procedural and recognized based justice for energy production and consumption. While speaking about energy systems, all parts of the process are included such as mining, conversion, production, transportation, distribution, consumption and waste. Discussion about energy justice has potential to become a new framework which brings together research on energy production and consumption and on the ways how to achieve the goals of fair and just energy processes.

Speaking about energy transition, the term frequently used by politicians to describe decarbonization of energy generation, Heffron and McCauley [60] highlight the issue of the just transition, which addresses issues of energy justice, climate justice and environmental justice. Energy justice should also refer to the application of the concept of human rights across the entire energy lifecycle. Such just transition should also address principles of output and distribute justice while involving all stakeholders into decision-making processes and equally distributing burdens, risks and benefits of the energy transition process.

In relation to Arctic, the fair energy policy should address the question of the location of power plants and mining activities in the vicinity of indigenous people. It should also provide opportunities for indigenous people to engage into decision-making processes which affect their communities, their cultural values and way of life. Output justice of energy generation, transmission and distribution should be provided while burdens, risks and benefits of these activities are distributed equally among various groups and various level of governance. Procedural justice is not only about participation in decision-making processes, but it is also about mobilization of local knowledge. In this regard, various authors, also including Jenkins et al. [59], are calling for stronger protection of right of indigenous people such as Sami people who are spread across northern parts of Norway, Sweden, Finland and Russia and whose communities are heavily dependent on local ecosystems.

Understanding social sustainability is also closely linked to the issue of participatory management. With regard to the development of industrial commodities and infrastructure, participatory management is understood as a mechanism that facilitates the involvement of various stakeholders and social groups in the project in order to gather their feedback on the company's vision of the role in the region and the possibility of creating social infrastructure [61] and the details of project implementation, which also include transparency and accountability [62]. Data on European infrastructure projects show that joint management of infrastructure project planning has helped to implement projects with less social protests and negative consequences as well as more positive impact on local communities [56,63-66].

In this study, with regard to offshore oil and gas projects in the Arctic, we believe that the social aspect of sustainability should be reflected primarily through the creation of new competencies and new jobs. The social sustainability of a project means, among other things, new jobs and an increase in the requirements for staff competence, which in its turn will mean increasing the human potential of an oil and gas company.

\subsection{Definition of "Strategic Sustainability"}

Further, following the logic of this study, it is necessary to move to the concept of "strategic sustainability". In our opinion, strategic sustainability is the basis for the long-term development of a company or project. A project's strategic sustainability factor is important in an environment where offshore hydrocarbon production involves huge capital and operating costs, long payback periods and high uncertainty associated with price volatility and global environmental and geopolitical trends.

According to Sabanchiev [67] strategic sustainability refers to a certain ability of an industrial system (project, company), which is based not only on maintaining the integrity of the structure but 
also on achieving and developing strategic goals in a continuously changing (or variable) environment. In this interpretation, the strategic sustainability of a system (project/company) is achieved by establishing a balance between manageability (degree of control) and flexibility (mobility of the organization). In his scientific paper "Flexibility, manageability and strategic sustainability: concepts, relationships and evaluation" Sabanchiev presents an attempt to qualitatively assess the potential of flexibility and manageability of the organization, which will confirm the presence or absence of strategic sustainability.

In the scientific work of Galitskaya [68], strategic sustainability is aimed not only at the efficient use of production resources and the preservation of financial and economic stability over a long period of time under the conditions of a changing internal and external environment but also at increasing the cost of capital, which contributes to the sustainability of the industrial system, investment attractiveness and growth of income of its owners.

In his dissertation research, Dudin [69] strategic sustainability is viewed in terms of competitiveness and is expressed as a set of "manageable dynamic components" that ensure the continuous development of companies (organizations) in the right (right, right) balance. This is the ability to create, develop and maintain competitive advantages in a segmented commodity market for a long time, thus maintaining a proper level of liquidity, solvency and profitability of the industrial system in the conditions of changes in the external environment. The proposed definition of strategic sustainability considers competitiveness to be the "ability to produce or obtain and successfully implement innovations", which give rise to significant advantages that allow the company (organization) to move to a new modern level of development.

Kucheryavy in his scientific work [70] writes that the competitive advantages of the company's strategic sustainability include "the ability to adapt to current environmental requirements" (flexibility), development and growth of benefits and "compliance with the tactics of the moment" (innovation potential).

Baranenko and Shemetov [71] believe that strategic sustainability is the maintenance over a long period of time of the growing trend expressed by the system of key performance indicators of the industrial system. In this book, the authors consider strategic sustainability from three main aspects: financial sustainability, technological sustainability and organizational sustainability.

According to Terentyeva [72], ensuring strategic sustainability primarily means increasing market share and maintaining a leading position on the market and developing competitive advantages, including the development of innovative products.

The author Rychikhina [73] proves that the strategic stability of the industrial system is expressed through minimization of losses due to adverse environmental impacts, and under favorable circumstances-in the ability to effectively increase their assets, both tangible and intangible, which increases the survival of the enterprise in the event of adverse changes in the external environment in the future.

A critical analysis of the definitions is presented above showing that the authors are closer to the concept of sustainability. However, in the case of offshore oil and gas projects, these definitions are not suitable for strategic sustainability, since most of them do not reflect technological and socio-environmental aspects.

Alonzi in his scientific work "What is Project Sustainability?" [74] speaks about sustainability as the ability of the organization (company) to achieve its mission (strategy) in the long term. Looking at projects as temporary structures, Alonzi focuses on the fact that the result (or impact) of a project must be continued and developed after the project itself.

Many large Russian and foreign companies research strategic sustainability issues within the framework of corporate sustainability by publishing sustainability reports, based on which they define and highlight economic, environmental and social aspects of sustainability. According to Baumgartner and Ebner [75], strategic orientation and sustainability development of companies must be designed on the basis of an effective resolution of the existing problems (weaknesses) of the company (organization, 
projects), but in many cases, there is no link between the identified problems and the sustainability strategies of the company (organization, projects) in practice.

Baumgartner in the scientific work "Strategic perspectives of corporate sustainability management to develop a sustainable organization" [76] presents sustainable development as economic, environmental and social development that meets the needs of the present and does not prevent future generations from meeting their needs. This study reveals the relationship between strategic management and sustainable development, providing an open discussion for further empirical research.

Martens and Carvalho in their scientific work "Key factors of sustainability in project management context: A survey exploring the project managers' perspective" [77] identify four key factors that will contribute to the strategic sustainability of the company (organizations, projects): a sustainable innovative business model, stakeholder management, economic and competitive advantages, and environmental policy and resource saving.

Tharp in her scientific research "Project management and global sustainability" [78] speaks about the methods of sustainable development of the company (organization) as responsibility for the impact of its activities on customers, employees, shareholders, community and the environment in all aspects of its operations. This article focuses on the interdependence between companies and society as a whole, covering the following aspects: human rights, labor practices, the environment (sustainable use of resources, pollution prevention and climate change mitigation), fair operating practices (combating corruption, fair competition and respect for property rights), consumer issues (fair contract practices, dispute resolution and fair marketing), and community engagement.

Thus, the authors also define strategic sustainability as a set of financial, technological, market, environmental, social and other types of sustainability. These definitions: Alonzi [74], Baumgartner and Ebner [75], Baumgartner [76], Martens and Carvalho [77], Tharp [78]—are more appropriate for understanding the strategic sustainability of an offshore oil and gas project but do not reflect the specifics of the offshore fields, implementation environment or technology. It must be emphasized that here there are gaps in the theoretical basis for the definition of "strategic sustainability" of high-tech and archaically complex offshore oil and gas projects in the Arctic from a technical and managerial point of view.

\subsection{Strategic Sustainability of the Offshore Oil and Gas Project}

The offshore oil and gas project in the Arctic addresses a complex set of technological challenges. Its characteristics are related to geological, technological, macroeconomic, environmental and geopolitical factors. The financial efficiency of such a project is important, but it is equally important to develop the innovative component of the company, that is, unique technological solutions that can be used in the implementation of the project: the use of ice-resistant platforms or subsea production complexes, new exploration methods or transport and logistics technology systems will provide the company with a sustainable competitive advantage for several years ahead.

In addition, it is important to recognize that the long-term realization of the project is likely to be associated with market changes, falling or rising oil prices, reduced demand, increased impact of green energy in the face of $\mathrm{CO}_{2}$ emissions reductions and the adoption of a number of international conventions (Paris Agreement and others) and substitution of traditional energy sources with alternatives. In particular, there are a number of other international agreements and target documents aimed at combating climate change. We put here citation from [79]: "Alongside its $\mathrm{CO}_{2}$ commitments for 2030 and 2050, the EU should contribute to international efforts to limit emissions of short-lived climate pollutants such as black carbon and methane that further accelerate climactic changes in the Arctic. Coming from soot and up to 1500 times more powerful than $\mathrm{CO}_{2}$, black carbon increases the melting rate of ice and snow. Methane is another greenhouse gas, 20 times more potent than $\mathrm{CO}_{2}$, with vast reserves projected to be stored under the Arctic permafrost. The EU could limit emissions through the Convention on Long-Range Transboundary Air Pollution (UNECE CLRTAP); the amended Gothenburg Protocol, the Commission's Air Quality Package proposal; the Climate and 
Clean Air Coalition; and engagement with Arctic Council initiatives such as the Task Force on Black Carbon and Methane".

All of these factors and limitations, which may also occur internationally, must be taken into account and taken into account by the company which must have alternative options for project implementation - to complete the project with commercial benefits. Environmental risks in the implementation of offshore oil and gas projects are very high-in this regard, the company must provide for the reliability of its technological systems, provide access to reliable oil spill response technologies and so on.

The authors believe that a systematic approach to assessing the sustainability of offshore Arctic oil and gas projects is appropriate. Summarizing the definitions of sustainability and strategic sustainability in the literature review presented above in the Sections 2.1-2.3 and complementing these definitions with the specifics of Arctic offshore oil and gas projects and their missions, including their social and environmental component, the authors propose four approaches to defining "strategic sustainability" - process, marginal, systemic, and competitive advantage-based (Figure 1).

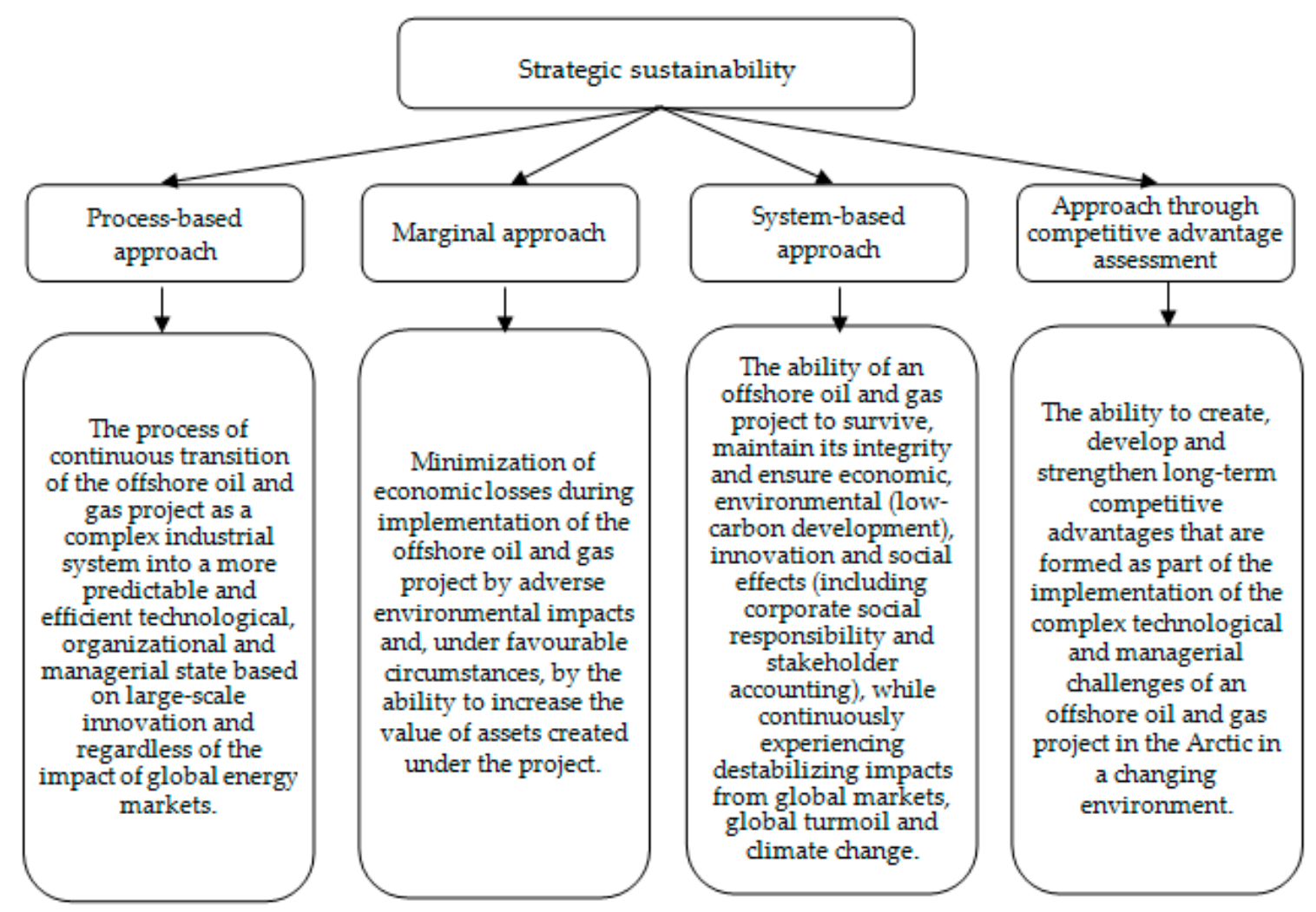

Figure 1. Classification of approaches to the definition of "strategic sustainability" of the offshore Arctic oil and gas project. Source: authors self-elaboration.

In general, the term "strategic sustainability" for an oil and gas Arctic offshore project should be understood as continuous improvement within the framework of the project, while achieving strategic goals and the ability to survive and preserve the long-term character of development under conditions of various risk events and phenomena, and above all under conditions of trends of $\mathrm{CO}_{2}$ emission reduction and reduction in the use of fossil fuels in the global energy industry and thus unpredictable development of the situation on the world markets of energy carriers and products of their processing.

In this regard, the high risks of offshore Arctic oil and gas projects must be highlighted. Different aspects of risks are well reflected in the studies [80-91]. These studies describe in detail the subjective perception of risks, financial risks, management risks, project management risks and risks associated with social opposition. 


\subsection{Risks of Offshore Oil and Gas Projects}

This study should address the specific risks of offshore oil and gas projects.

Voronina [92] and Fadeev et al. [93,94] believe that the development of hydrocarbon resources, particularly in the Arctic under extreme climatic conditions, the low sustainability of environmental systems and the complexity of engineering and transport infrastructure, is associated with the high capital intensity, complexity and heterogeneity of social processes, which makes offshore projects highly risky. Voronina in her paper [92] proposes the following division of the risk universe of Arctic shelf oil and gas development projects: geological risks, technical risks, transport risks, environmental risks, social risks, political risks, financial risks, including investment and commercial risks. The authors agree with this division. Let us characterize the main risks.

Geological risks arise during geological exploration and are due to insufficient study of the shelf, as well as high costs of drilling. These risks are manifested in the absence of oil and gas potential and non-confirmation of reserves.

Fadeev et al. [94], apart from technical risks, also highlight technological risks. Technological assessment of the availability of reserves for commercial development of a field is determined on the basis of the possibility of using existing technical facilities as well as prospective technical developments that can be used for fields at later stages of development. It should be noted that the factor of technological availability of fields in the Arctic region is the first basic criterion for their differentiation by industrial importance.

At present, real field development technologies exist only for the transit zone and the part of the shelf where there is no continuous ice.

Technologically inaccessible reserves and resources are allocated in those areas where, due to geological or climatic conditions, there are no actually working technologies for the industrial development of identified oil and gas fields. In particular, this factor is critical in those areas of the Arctic shelf where ice is distributed at significant sea depths [94].

Technological and transport risks of the development stage, typical for the shelf of the Northern seas, are associated with the complexity (and sometimes lack) of technologies, increased probability of equipment failure (especially in Arctic conditions), lack of experience in the transportation of hydrocarbons in significant volumes, shortage of tankers and icebreakers, etc. [94]. The choice of technology and technical means for the transportation of resources is determined by the influence of a number of factors: the geographical position of the water area, the depth of the sea, the volume of transported products, the distance of transportation, etc.

Perspectives on the development of offshore fields in Russia are also associated with areas that are characterized by heavy and very heavy ice conditions and relatively small depths of the sea. These include the Pechora sea, the Sakhalin shelf, the Kara sea and the East Arctic waters [94]. There are very significant differences between these areas in terms of transport infrastructure. The Sakhalin shelf with small distances of transportation of production to the coast is especially allocated. In addition, the infrastructure for oil and gas production is already developed on the Sakhalin coast, adjacent to the sea fields. In such conditions, for the Sakhalin shelf fields, it seems appropriate to focus on the laying of pipelines from each field to the shore, followed by their connection to the coastal communications. Therefore, there appears a whole complex of technical and technological tasks applicable to shallow-water gas pipelines. The only fundamental difference is the absence of permafrost on Sakhalin.

In the rest of the Arctic, the situation is fundamentally different: here either there are no communications with the coastal zone, or they are underdeveloped. To solve the problem of transporting oil in these conditions, it is necessary to construct loading terminals for tankers. At the same time, in order to ensure year-round oil transportation, for example, from the fields of the East Arctic seas, where the ice-free period is limited to 1.5-2.0 months, non-traditional means of transport such as icebreaker tankers will be required [94]. 
The development stage is also characterized by environmental risks associated with the possibility of causing serious damage to the environment and the subsequent costs of its liquidation and compensation.

This risk factor can occur at any stage of the operations, from offshore hydrocarbon production to the transportation of oil or gas products. As a result, the preservation of the Arctic's natural environment and its ecological balance can be disrupted, and people's livelihoods can be endangered. Global statistics show that offshore development and the transportation of oil and gas by water are among the most environmentally hazardous activities.

The nature of risks, their probability and potential damage at various stages of prospecting, exploration and development are analyzed. It should be borne in mind that oil spill incidents can have catastrophic consequences for the living resources of the Arctic seas. The potential damage may amount to tens of billions of dollars. In any case, the number of fines in the Russian Arctic shelf will be significantly higher than in the case of an oil spill by a tanker in the Pradho Bay field in Alaska or a fire on a platform operating in the Gulf of Mexico [94].

Accidents on offshore drilling platforms can be accompanied not only by extremely serious environmental consequences but also by large human victims due to the thermal effects of fire and the toxicity of combustion products, due to the limited platform area and evacuation difficulties.

Along with this, an analysis of accidents on oil and gas platforms shows a decrease in the number of accidents with catastrophic consequences in recent years (the death of a huge number of people, large-scale environmental pollution, major material damage), which may be associated with technological and design improvements of platforms and the use of modern security systems [94].

Legal regulations and liability insurance might help to reduce the risks, but sometimes the slightest mistake can lead to significant adverse consequences.

When approaching the moment of completion of the field, there are risks associated with the deterioration of equipment and infrastructure [94]. On the one hand, this leads to an increase in the environmental risks of the investor, as the probability of equipment failure and serious damage to the environment increases. On the other hand, after the completion of the project, the state remains with objects that are either not suitable for further use or require significant funds to maintain them in working condition.

There are liquidation risks, manifested in the possible absence of the subsoil users and the state of funds for the implementation of liquidation work [94]. In particular, the United Kingdom and Norway, which have long been producing oil and gas on the shelf, have already encountered such a problem. To reduce this risk, liquidation funds are created, and a deduction from the tax base of the costs of creating liquidation funds is made. According to Russian legislation, the formation of a liquidation fund - the most reliable mechanism for reducing liquidation risks-is possible only when using the production sharing mode.

Social risks are related to the possible negative consequences from the projects on the quality of life and the original culture of the people living in the Arctic region as well as the uneven distribution of benefits and risks of the projects between extracting companies and local communities. Such projects might also lead to the increased inequality within social groups and between various regions as well as to social instability. There is a need to strike a balance between the interests of extractive companies and the population of the Arctic territories, taking into account their ethnic characteristics, lifestyle which is closely connected to the nature and existing possibilities to participate in decision-making processes which affect their communities as well as the existence of social impact assessment regulation.

Risks of increased use of non-fossil fuel in connection with the fight against climate change. Global oil and gas companies forecast an increase in the share of renewable energy sources (RES) [95,96], and the Paris Convention and other documents dictate the need to develop zero emission and hydrocarbon development technologies. 
In particular, BP (formerly British Petroleum) stated that the time for the growing global demand for oil has passed. The need for fossil fuels has already peaked and will face an unprecedented decline over the next few decades. The Guardian [97] reports this with reference to BP's annual report.

In September 2020 BP published a report on its energy prospects [96]. According to the report, oil is likely to be replaced by clean electricity from wind farms, photovoltaic panels and other renewable energy sources.

According to the report [96], demand for oil will decline by 55\% over the next 30 years. If as many countries as possible comply with the Paris Climate Agreement, demand for oil will fall by $80 \%$ by 2050 .

The growing popularity of electric cars may also have an impact on the demand for oil. Another factor that is reducing the demand for oil in the coming years is the new measures to restrict plastic, which requires petrochemical products made from fossil fuels.

In August 2020 BP presented plans to increase its investment into low-carbon technologies eightfold by 2025 and tenfold by 2030, reducing fossil fuel production by $40 \%$ compared to 2019 [92]. In September 2020, the company took its first step in the offshore wind energy business by investing $\$ 1.1$ billion [97].

This means that other oil and gas companies will also diversify into low-carbon development projects. There may be a decline in demand for fossil fuels, and this will make expensive offshore projects impossible - the era of high oil prices will be gone forever.

The development phase is also characterized by high economic risks associated with high capital intensity and duration of offshore development projects. Thus, even a slight increase in costs can lead to a significant increase in the payback period and reduce the return on invested capital [94]. This circumstance places special emphasis on the management of the development of offshore oil and gas fields.

In addition, the indicators arising from the volume of reserves and geological resources are deterministic and therefore do not sufficiently consider the investment risks associated with their non-confirmation, especially in the initial stages of exploration. This should be taken into account when planning exploration and field development on the Arctic platform, where the cost of drilling each well can be in the hundreds of millions of dollars [94].

There are also risks of emergency situations in the Arctic, which are discussed in scientific works [98]:

- Natural character: dangerous hydrometeorological phenomena, morphology and dynamics of the Arctic seashore, the impact of ice formations, gas hydrates, geological and natural processes hazardous to oil and gas industry structures on the Western Arctic shelf of Russia, permafrost degradation;

- Risks of oil spills, risks of permafrost facilities, risks of gas transportation on the sea floor, risks of accidents at hydroelectric power plants built in the permafrost zone, risks of accidents at potentially hazardous industrial enterprises, risks of shipwrecks in the Arctic seas, risks of aviation accidents in the Arctic;

- Ecological character: anthropogenic disturbance of the natural landscapes of the Arctic zone, environmental risks of oil spills on the Arctic platform, the impact of climate change on the Arctic environment [99];

- $\quad$ Risks associated with the use of the Northern Sea Route [98,100].

Analysis of these risks shows that the implementation of projects to develop oil and gas resources of the Arctic platform requires the resolution of various problems: the implementation of projects in the Arctic conditions requires the introduction of non-trivial measures of innovative nature, which in turn increases the risks. Therefore, it is necessary to be able to analyze, assess and manage risks rather than avoid them.

Fixing the values of changes in project development over a long period of time allows us to identify a trend. Any trend can be expressed through trends that are rising and falling. In order to achieve 
strategic sustainability, the project, its timing and economic performance must strive to establish and maintain an upward trend [94]. Strategic sustainability has several aspects: achievement of a certain level of indicators within a given timeframe (these can be both natural and cost indicators-in particular profitability), project repeatability or replicability, and risk tolerance.

With regard to the criteria for assessing the strategic sustainability of an offshore oil and gas project, the authors note the need to assess the project from the point of view of the geological verifiability of reserves, technological equipment, financial efficiency and social and environmental factors.

\section{Materials and Methods}

The research materials are monographs and scientific articles, applied works of Russian and foreign scientists devoted to the theory and practice of strategic management in the oil and gas complex. In the course of the research, periodicals and materials from scientific and practical conferences were also used. The method of hierarchy analysis was used in the study.

\subsection{Criteria for Assessing Strategic Sustainability}

Based on the studies conducted in Section 2, the authors consider it appropriate to identify the following key strategic sustainability objectives affecting the sustainable development of Arctic marine projects—investment, technological, geological, social and environmental (Table 1).

Table 1. Strategic sustainability goals for marine projects in the Arctic.

\begin{tabular}{cl}
\hline Objectives & \multicolumn{1}{c}{ Description } \\
\hline Investment & $\begin{array}{l}\text { It is necessary to understand the profitability of the projects and the } \\
\text { limits of the project cost per unit. It is also very important to understand } \\
\text { and predict the level of exploration costs due to the low degree of } \\
\text { exploration of offshore fields in the Arctic. }\end{array}$ \\
Implementation of projects in the Pechora, Kara and Eastern Arctic Seas \\
will require the development of new technical solutions and the \\
adaptation of existing ones. Technological sanctions from the USA and \\
EU countries make project implementation difficult. \\
The success and sustainability of reserves growth are the most \\
important targets for the offshore oil and gas project in the Arctic. \\
The Company has the set of knowledge and experience required for the \\
customer to implement current stages of projects. The full range of \\
offshore competencies currently lacking in many Russian oil and gas \\
companies and in the country as a whole may be in demand for the \\
implementation of offshore Arctic projects. \\
Ensure environmental safety and biodiversity conservation at \\
exploration and mining sites. Zero CO $\mathrm{CO}_{2}$ emissions projects are also an \\
important objective.
\end{tabular}

Source: authors self-elaboration.

The authors propose to develop a methodology for assessing the strategic sustainability of offshore projects, taking into account the objectives set out in Table 1 and identifying specific criteria for these projects based on them. The strategic sustainability will be assessed on the basis of an integral sustainability indicator.

The grinding projects considered by the authors form a significant resource potential (geological resources of about 15 billion tons of oil equivalent) [94]; however, they are at the "Search" stage and are characterized by varying degrees of complexity and geological and geophysical exploration, which determines a significant range of assessment of their technical and economic performance.

The study examined 5 projects located in the Pechora, Kara and Eastern Arctic Seas, all of which are in the exploration phase.

The specific criteria for offshore oil and gas projects for which a new methodology is being developed are divided into two levels-sustainability groups and indicators that characterize them 
effort consuming for the decision maker (regardless of the number of alternatives being evaluated) and the need for accurate quantitative measurements of the weighting characteristics of the decision maker's evaluation criteria;

- Lotfi Zadeh suggested methods based on the theory of fuzzy sets in his works [104,105]. The theory of fuzzy sets, although usually used in practical applications on its own, is in a sense reduced to random set theory and thus to probability theory;

- Methods based on quantitative measurements but using several indicators when comparing alternatives-group of methods ELECTRE (Elimination Et Choix Traduisantla Realite); developed in his works Bernard Roy $[106,107]$. The plus of the methods was that there was no need for a one-stage definition of the decision maker's preferences and that it was possible to form opinions gradually and reasonably well-founded. However, the disadvantage of the methods was the complexity of the process of determining coefficients of significance and the possibility of erroneous opinions in the selection of nuclei with minimal dominance of one structurally complex alternative over another;

- Methods based on qualitative measurements, without moving to quantitative variables (Verbal Decision Analysis (VDA)) [108,109]. Most decision makers recognize the deep contradictions between the requirements of regulatory methods and the capacity of the human information processing system. An attempt to overcome these contradictions is the verbal decision analysis approach based on psychological criteria, i.e., these methods take into account cognitive and behavioral aspects. However, the task of singling out the best of multi-criteria alternatives is quite complex for a person: thus, when singling out a subset of the best alternatives, subjects can remove the dominant alternatives and leave the dominant ones behind. In addition, there may be a situation where cycles appear on the multitude of alternatives being compared;

- Simple multi-criteria assessment method SMART, first formalized and developed in the works $[110,111]$, is notable for its simplicity and reliability in practical application. In addition, the sensitivity check for weight changes makes it possible to take into account the impact of inaccuracies in measurements and the possible relationship between criteria. However, this method does not take into account the possible dependence of measurements and is not additive in determining the overall value of the alternative;

- Methods based on qualitative measurements, the results of which are converted into quantitative form-methods of analytical hierarchy (AHP-Analytic Hierarchy Process). This method was developed by the American mathematician Saati, Thomas L. [112,113]. The method of hierarchical analysis is used worldwide to make decisions in situations ranging from interstate management to commercial and private problems in business, industry, healthcare and education. Along with mathematics, it is also based on psychological aspects.

AHP does not define the "right" solution for the decision maker (DM) but allows the decision maker to interactively find an alternative that best meets their understanding of the problem and the requirements for solving it.

With the help of the AHP, it is possible to structure the complex problem of decision-making in a hierarchical manner clearly and rationally, and to compare and quantify alternative solutions.

The analysis of the decision-making problem in the AHP begins with the construction of a hierarchical structure that includes the objective, criteria, alternatives and other factors affecting the election. This structure reflects the decision maker's understanding of the problem.

Each element of the hierarchy may represent different aspects of a problem, taking into account both material and non-material parameters, measurable quantitative and qualitative characteristics, objective data and subjective expert assessments. In other words, the AHP's analysis of the decision-making situation is no different from the argumentation processes and methods used at an intuitive level.

The next step in the analysis is to identify priorities that reflect the relative importance or desirability of elements of the hierarchical structure that has been built using a paired comparison 
procedure. Unbalanced priorities allow for the reasonable exposure of heterogeneous factors to comparison, which distinguishes AHP significantly.

The Saati method is based on a paired comparison of alternatives for each criterion and a comparison of criteria in pairs, taking into account the importance of the objective. All comparisons in this method are therefore made in pairs, i.e., in the simplest and most obvious way.

For comparison, Saati suggested applying qualitative features, which are then converted into quantitative features on a 9-point scale (although it is possible that an object may be more than 9 times larger than another criterion, this scale is usually sufficient to reflect a qualitative ratio). If the DM cannot choose between two qualitative characteristics, if there is an intermediate opinion, Saati recommends using intermediate points $2,4,6,8$. These comparison possibilities can be defined in various ways: by subjective opinion, expert evaluation, voting, etc.

At the final stage of the analysis, a synthesis of hierarchical priorities is carried out, with the priorities of alternative solutions calculated in relation to the main objective. The best alternative is the one that has the highest priority value.

Despite the need to solve the task from scratch in the event of the emergence of any new alternative that was not originally envisaged and the peculiarity of the method of transition from qualitative to quantitative measurements, this method has undeniable advantages: the obvious focus of the decision maker's efforts on comparing the existing alternatives, which, with a small number of them, objectively reduces the labor intensity of the entire process; also, this method is not required to absolutize certain estimates. With the help of the AHP, it is possible to structure the complex problem of decision-making in a hierarchical manner clearly and rationally and to compare and quantify alternative solutions.

In this regard, we consider the hierarchy analysis method (AHP) to be the most appropriate one for assessing the strategic sustainability of offshore oil and gas projects-a mathematical tool for a systematic approach to complex problems in decision-making.

The algorithm proposed by the authors is to compare the evaluation criteria using the scale of relations by Saati, further building a normalized matrix, finding a priority vector and then evaluating the level of matrix inconsistency. This is done for each level of evaluation criteria for offshore oil and gas projects.

Let us consider this algorithm using the Company's Arctic oil and gas projects as an example. Therefore, the assessment of the strategic sustainability of the Company's Arctic oil and gas projects begins with a pairwise comparison of existing assessment criteria. To compare the relative importance of the criteria, we will use the scale of relations by Saati [113] (Table 3).

Table 3. Scale of evaluation of hierarchies by Saati.

\begin{tabular}{cll}
\hline Meaning & \multicolumn{1}{c}{ Interpretation } \\
\hline 1 & - & equivalence \\
3 & - & moderate superiority \\
5 & - & strong superiority \\
7 & - & very strong superiority \\
9 & - & highest (extreme) superiority \\
$2,4,6,8$ & - & appropriate intermediate values \\
\hline
\end{tabular}

Further on, we are moving to the description of the results from our survey.

\section{Results}

The authors involved experts from four companies: Gazprom Neft PJSC (Saint Petersburg, Russia), Gazprom Neft-Sakhalin LLC (Saint Petersburg, Russia), Rosneft PJSC (Saint Petersburg, Russia) and 
Gazprom Neft Shelf LLC (Saint Petersburg, Russia). The survey was impersonal, 14 experts were selected, and the level of positions ranged from chief specialist to head of department. The experts assigned points, each in their own table (Tables 4 and A2-A6 (see Appendix A)).

Table 4. Evaluation of Level 1 criteria.

\begin{tabular}{cccccc}
\hline Criteria & $\begin{array}{c}\text { Investment } \\
\text { Sustainability }\end{array}$ & $\begin{array}{c}\text { Technological } \\
\text { Stability }\end{array}$ & $\begin{array}{c}\text { Geological } \\
\text { Stability }\end{array}$ & $\begin{array}{c}\text { Social } \\
\text { Sustainability }\end{array}$ & $\begin{array}{c}\text { Environmental } \\
\text { Sustainability }\end{array}$ \\
\hline $\begin{array}{c}\text { Investment } \\
\text { sustainability }\end{array}$ & $1 / 1$ & $1 / 2$ & $1 / 3$ & $3 / 1$ & $3 / 1$ \\
$\begin{array}{c}\text { Technological } \\
\text { stability }\end{array}$ & $2 / 1$ & $1 / 1$ & $1 / 3$ & $3 / 1$ & $3 / 1$ \\
$\begin{array}{c}\text { Sustainability in } \\
\text { terms of geology }\end{array}$ & $3 / 1$ & $3 / 1$ & $1 / 1$ & $4 / 1$ & $3 / 1$ \\
Social sustainability & $1 / 3$ & $1 / 3$ & $1 / 4$ & $1 / 1$ & $1 / 3$ \\
Environmental & $1 / 3$ & $1 / 3$ & $1 / 3$ & $3 / 1$ & $1 / 1$ \\
sustainability & 6.67 & 5.17 & 2.25 & 14.00 & 10.33 \\
Amount & \multicolumn{2}{c}{ Source: results of the experts' evaluation. }
\end{tabular}

Source: results of the experts' evaluation.

Let us look at the first level criteria. The results of the expert evaluation are presented in Table 4. The table presents the average results of the peer review.

Experts' evaluations will be explained. For example, in Table 4, investment sustainability in relation to technological sustainability has a score of $1 / 2$ (accordingly, technological stability in relation to investment stability is estimated at $2 / 1$ ) - this means that experts believe that the importance of technological sustainability indicators "moderately exceeds" the importance of investment sustainability indicators. Moreover, the geological sustainability assessment for environmental sustainability has a $3 / 1$ rating (respectively, environmental sustainability in relation to geological sustainability is estimated at $1 / 3$ ) - this means that geological sustainability has a "strong advantage" over environmental sustainability, etc.

The next step is to build a normalized matrix. For this purpose, we divide the sum of each column into each column element. The results of the calculations are in Table A1 (see Appendix A).

We will find a priority vector for the first level criteria. For this purpose, each sum of rows in the previous table will be divided by the number of elements. The results of the calculations are presented in Table 5.

Table 5. Calculation of the first level criteria priority vector.

\begin{tabular}{lc}
\hline \multicolumn{1}{c}{ Level 1 Criteria } & Meaning \\
\hline Investment sustainability & 0.18 \\
Technological stability & 0.23 \\
Sustainability in terms of geology & 0.42 \\
Social sustainability & 0.06 \\
Environmental sustainability & 0.11 \\
\hline
\end{tabular}

Source: calculations by the authors.

As the columns of the normalized matrix are not identical, the original comparison matrix must be checked for consistency. To do this, we multiply the comparison matrix by a priority vector. Then we find the consistency index. If the index does not exceed 0.1 , then the matrix is found correctly. Calculations have shown that the level of inconsistency is acceptable $(0.09<0.1)$.

The next step was to build a matrix of paired comparisons of the second level elements against each of the first level criteria. For each matrix, a priority vector, consistency factor, stochastic consistency factor and consistency factor were calculated. The average results of the expert evaluation are presented in Tables A2-A6 (see Appendix A). 
The next step is to build a normalized matrix. To do this, we divide the sum of each column into each column element. The results of the calculations are in Tables A7-A11 (see Appendix A).

We will find a priority vector for the second level criteria (see Table 6). To do this, divide each sum of rows in Table A9 of Appendix A by the number of elements.

Table 6. Calculation of the second level criteria priority vector.

\begin{tabular}{lc}
\hline \multicolumn{1}{c}{ Level 2 Criteria } & Meaning \\
\hline Commissioning time & 0.09 \\
UTC (Unit Total Cost) & 0.23 \\
EMV (Expected Monetary Value) & 0.47 \\
Expenditure on the geological exploration program & 0.19 \\
Technological possibility of project implementation & 0.12 \\
Sanctions & 0.67 \\
Oil and gas field complexity category & 0.29 \\
Potential for accumulated production & 0.17 \\
Success evaluation & 0.18 \\
Difference in accumulated production P10/P50 & 0.20 \\
Geological exploration & 0.45 \\
New jobs & 0.13 \\
Inflow of highly qualified staff into the project from other companies & 0.25 \\
Growth of competencies of company employees implementing the project & 0.38 \\
Mechanisms for feedback from public organizations and regional management structures & 0.24 \\
Reliable oil spill response technology & 0.20 \\
Preservation of marine ecosystems and biodiversity & 0.46 \\
Minimization of CO ${ }_{2}$ emissions during extraction and transportation & 0.14 \\
Creation of additional insurance funds of a financial nature & 0.19 \\
\hline
\end{tabular}

Source: calculations by the authors.

As the columns of the normalized matrix are not identical, we also checked the original comparison matrix for consistency. Our calculations have shown that the level of inconsistency of this matrix is also acceptable $(0.07<0.1)$.

Total investment sustainability index (ISI):

$$
\mathrm{ISI}=w_{1} \times \text { Termission period }+w_{2} \times \mathrm{UTC}+w_{3} \times \mathrm{EMV}+w_{4} \times \text { Program costs, }
$$

where $w_{i}$ is the weight of the respective factors selected for the investment sustainability study.

Generalized technological stability indicator (TSI):

$$
\begin{gathered}
\text { TSI }=w_{1} \times \text { Technological feasibility of project implementation }+w_{2} \times \text { Sanctions }+ \\
w_{3} \times \text { Category of complexity, }
\end{gathered}
$$

where $w_{i}$ is the weight of the respective factors selected for the technological stability study.

Generalized geological stability indicator (GSI):

$$
\begin{aligned}
\text { GSI }= & w_{1} \times \text { Success Potential of Accumulated Production }+w_{2} \times \text { Success Assessment }+ \\
& w_{3} \times \text { Accumulated Production Difference P10/P50 }+w_{4} \times \text { Geological Survey, }
\end{aligned}
$$

where $w_{i}$ is the weight of the respective factors selected for the geological stability study.

Total Social Stability Index (SSI):

SSI $=w_{1} \times$ New jobs $+w_{2} \times$ Inflow of highly qualified personnel into the project from other companies $+w_{3} \times$ Competence gap of employees implementing the project + $w_{4} \times$ Mechanisms for feedback from public organizations and regional structures,

where $w_{i}$ is the weight of the relevant factors selected for the social sustainability study. 
Generalized Environmental Sustainability Index (ESI):

$\mathrm{ESI}=w_{1} \times$ Sustainability of oil spill response technologies $+w_{2} \times$ Saving marine ecosystems and biodiversity $+w_{3} \times$ Minimizing $\mathrm{CO}_{2}$ emissions during extraction and transportation $+w_{4} \times$ Creating additional financial insurance funds,

where $w_{i}$ is the weight of the respective factors selected for the environmental sustainability study.

The strategic sustainability of the projects (SSP) will be based on a formula:

$$
\mathrm{SSP}=0.18 \times \mathrm{ISI}+0.23 \times \mathrm{TSI}+0.42 \times \mathrm{GSI}+0.06 \times \mathrm{SSI}+0.11 \times \mathrm{ESI},
$$

where ISI is investment sustainability; TSI is technological sustainability; GSI is geological sustainability; SSI is social sustainability; ESI is environmental sustainability; and 0.18,0.23, 0.42, 0.06 and 0.11 are weights of the first level criteria presented by the experts (see Table 5). The calculation of the strategic sustainability of the projects is presented in Table 7.

Table 7. Calculation of the strategic sustainability of the Company's offshore projects.

\begin{tabular}{ccccccc}
\hline Project & ISI & TSI & GSI & SSI & ESI & Strategic Sustainability of the Project (SSP) \\
\hline Project 1 & 0.8 & 1.3 & 1.7 & 1.32 & 1.20 & 1.37 \\
Project 2 & 1.7 & 2.9 & 1.0 & 2.15 & 0.95 & 1.64 \\
Project 3 & 0.6 & 2.5 & 0.8 & 1.62 & 1.51 & 1.29 \\
Project 4 & 1.2 & 1.5 & 1.5 & 1.28 & 0.35 & 1.31 \\
Project 5 & 0.4 & 0.7 & 1.3 & 0.99 & 1.02 & 0.95 \\
\hline
\end{tabular}

Source: calculations by the authors.

To make it clear which offshore projects are more strategically sustainable and which are less so, we suggest building a matrix consisting of two quadrants (see Figure 2). On the vertical axis, we will postpone the strategic stability values obtained for offshore projects, with a maximum of 1.7 and a minimum of 0.8 for the vertical axis. The horizontal axis corresponds to the middle of this interval-the value of 1.25. Projects falling in the upper quadrant (for our calculations SSP $\geq 1.25$ ) are strategically stable, and projects falling in the lower quadrant (SSP < 1.25) are less strategically stable.

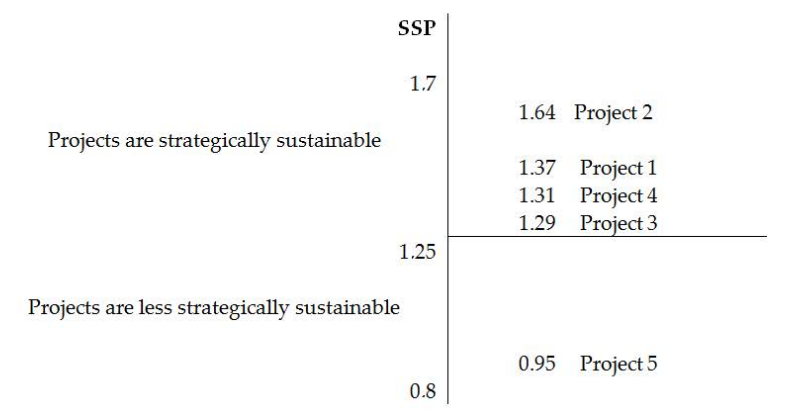

Figure 2. Interpretation of the calculation of the strategic stability of the Company's offshore projects. Source: authors self-elaboration.

Hence, Project $2(\mathrm{SSP}=1.64)$, Project $1(\mathrm{SSP}=1.37)$, Project $4(\mathrm{SSP}=1.31)$ and Project $3(\mathrm{SSP}=1.29)$ are the most strategically sustainable.

Project $5(\mathrm{SSP}=0.95)$ is less strategically sustainable; they are long-term investment projects that require the development of new technological solutions during the transition to operations but have a significant level of reserves.

Of course, the achieved results should be discussed, and the authors are ready to offer critical comments and opportunities for improving approaches to strategic sustainability assessment and will consider these aspects further. 


\section{Discussion}

The proposed methodology is mathematically sound and takes into account the specifics of offshore oil and gas project evaluation.

The proposed strategic sustainability assessment algorithm includes an assessment of various aspects of implementing offshore oil and gas projects. When gathering long-term information on the strategic sustainability indicator, it is possible to draw conclusions about the project's development trends and provide recommendations on its development. However, we do not believe that the system of criteria is conclusive. Such a system must be developed taking into account the changes taking place in the global energy industry.

The authors proposed specific criteria for assessing the strategic sustainability of offshore oil and gas projects, divided into five groups: investment, technological, geological-field, social and environmental. The results obtained by the authors showed that the highest weight, according to experts, is given to geological stability -0.42 . The second most important group is technological sustainability -0.23 , followed by investment sustainability -0.18 , environmental sustainability -0.11 , and social sustainability-0.06. Currently, technical and geological factors of the project implementation are the most important among Russian managers and specialists, which in terms of long-term development and the possible impact of damage to the environmental stability of the Arctic raises some concerns. In our view, companies must strengthen their "sustainable development policy" and implement a set of measures to facilitate the development of offshore oil and gas projects in the Arctic under conditions of ecological balance and social orientation. Understanding the dynamics of global energy development and the importance of low-carbon technologies, it is advisable to supplement the strategic sustainability assessment with criteria related to the minimization of greenhouse gas emissions at all stages of the technological cycle, for example, assessing the possibility of using sequestration technologies in case of high $\mathrm{CO}_{2}$ content (in produced natural gas) or assessing the reduction of methane losses during transportation. The development of competencies, the role of innovative managers, the growth of social responsibility and the strengthening of relationships with public organizations are also key areas that must be taken into account when developing criteria for assessing the strategic sustainability of offshore oil and gas projects.

As a discussion, the authors also offer recommendations for the development of a strategic management system that will expand relevant assessment criteria and improve the quality of strategic sustainability assessment of marine projects in the Arctic (Table 8).

An important aspect that the authors would like to point out, and which is important for future generations and sustainability, is this: you cannot produce marine hydrocarbons unless you have a set of reliable measures in place that can preserve the Arctic's ecology. Marine projects must be ranked according to the degree to which environmental risks are minimized, and a set of criteria must be developed to ensure the safety of marine mining operations.

Particular attention needs to be paid to the Arctic shelf oil spills (see paragraph 5 of the Table 8 for this criterion) that could have serious environmental consequences. In the Arctic, it is important to highlight features that complicate the response to oil spills, such as the polar night, waves, currents, poor infrastructure and the lack of modern response equipment for Russian companies. Oil spill response methods need to be developed, but the authors suggest that the most important way to ensure the sustainability of offshore projects should be to reduce the probability of spills and minimize accidents in Arctic offshore fields.

Criteria related to ensuring environmental safety must be introduced into the system of strategic sustainability indicators.

For example, projects in which ecological risks can be managed are a priority for implementation. These are projects that involve the presence of technical means to reduce environmental risks and practical experience. Offshore projects, for example, may include those where drilling can be done from shore. 
In the light of the proposed recommendations, it is possible to further develop a system of indicators to be taken into account in assessing the strategic sustainability of offshore oil and gas projects.

Table 8. Development of offshore projects to further define criteria for strategic sustainability assessment.

\begin{tabular}{|c|c|}
\hline Areas of Development & Recommendations \\
\hline 1. Finance & $\begin{array}{l}\text { - Formation of mechanisms for attracting financing from partners and } \\
\text { delegation of geological risks at the exploration stage. } \\
\text { - Changing the methodology for investment assessment and } \\
\text { decision-making for projects with a long investment phase. }\end{array}$ \\
\hline 2. Technology & $\begin{array}{l}\text { - Implementation of the import substitution strategy_an increase in the } \\
\text { share of domestic equipment. } \\
\text { - } \quad \text { Use of technology partners and cluster mechanisms. } \\
\text { - } \quad \text { Development of interaction with suppliers. } \\
\text { - Development of digital technologies. }\end{array}$ \\
\hline 3. Logistics and infrastructure & $\begin{array}{l}\text { Ensuring safe use of technical means and industrial } \\
\text { safety development. } \\
\text { - } \quad \text { Ice situation management. } \\
\text { - } \quad \text { Development of the companies' own specialized fleet. } \\
\quad \begin{array}{l}\text { Development of a strategy to protect against dangerous ice } \\
\text { - }\end{array} \text { Developmena and negative temperatures. }\end{array}$ \\
\hline 4. People and processes & $\begin{array}{l}\text { - Developing technical competencies in offshore drilling, seismic, } \\
\text { engineering, logistics and HSE (health, safety and environment). } \\
\text { - } \quad \text { Management team development. } \\
\text { Development of project competencies, project management } \\
\text { methodology and formation of project teams. } \\
\text { Formation of methodology and development of competencies in } \\
\text { partnership management. }\end{array}$ \\
\hline $\begin{array}{l}\text { 5. HSE (health, safety and } \\
\text { environment) }\end{array}$ & 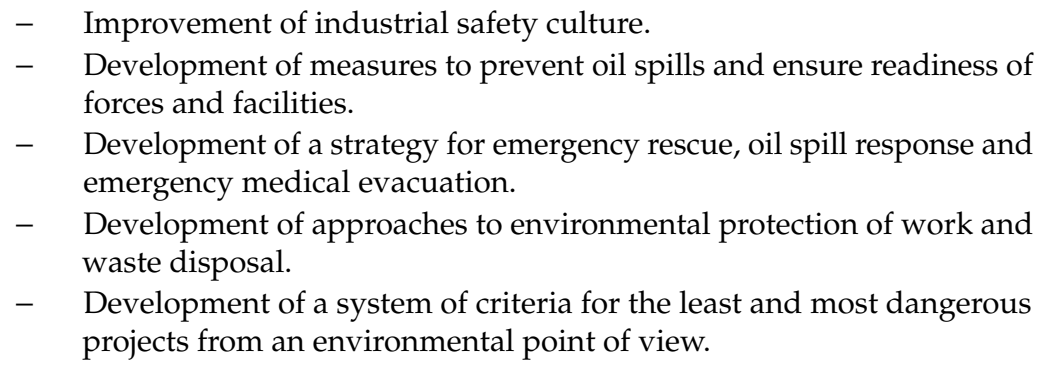 \\
\hline $\begin{array}{l}\text { 6. External interactions and } \\
\text { keeping track of global trends }\end{array}$ & $\begin{array}{l}\text { - } \quad \text { Attracting partners to implement offshore projects. } \\
\text { - } \quad \text { Interaction with the state (legal and regulatory support, elimination of } \\
\text { administrative barriers). } \\
\text { - } \begin{array}{l}\text { Development of new standards and harmonization of existing } \\
\text { standards to support offshore exploration, production }\end{array} \\
\text { and transportation. } \\
\text { - Search for development directions, taking into account the synergy } \\
\text { effect of developing active regions of marine and onshore production. } \\
\text { - } \quad \text { Accounting for low-carbon energy development. } \\
\text { Diversification of the oil and gas business. }\end{array}$ \\
\hline
\end{tabular}

The authors assume that the results of the author's study to assess the strategic sustainability of offshore hydrocarbon field development projects are applicable for making strategic decisions regarding the prospects for developing Arctic shelf fields. 


\section{Conclusions}

The authors have conducted studies of theoretical approaches to determining "the sustainability" of industrial systems and projects. The aspect that unites the approaches of different scientists to the definition of "strategic sustainability" is the long-term nature of environmental, social, economic and technological sustainability.

The authors propose a systematic approach, which defines strategic sustainability as the ability of an offshore oil and gas project to survive, preserve its integrity and ensure economic, environmental (low-carbon development), innovative and social effects (including corporate social responsibility and consideration of stakeholders' interests) with the constant destabilizing impact of global markets, global turmoil and the fight against climate change.

The key risks of offshore projects, such as technological, geological, financial, social, environmental, transport and other risks, have been identified, which together with the approach to the concept of "strategic sustainability" have allowed the development of a system of criteria for assessing the strategic sustainability of an offshore oil and gas project. The authors also highlighted the risks of increased use of non-fossil fuels due to climate change, which are not reflected in the system of indicators but may be a serious challenge that significantly limits the implementation of offshore oil and gas projects in the future.

Specific criteria for assessing the strategic sustainability of an offshore oil and gas project have been defined, including five groups of first level criteria: investment, technological, geological, social and environmental, with four (three technological) specific indicators-second level criteria. On the basis of these criteria, a comprehensive indicator assessing the project's strategic sustainability has been formed.

The methods for solving multi-criteria tasks were analyzed and the hierarchy analysis method was chosen as the most suitable method for the conditions of developing unique offshore oil and gas projects.

The strategic sustainability of existing offshore projects in the Russian Arctic shelf was assessed with the involvement of experts from the following companies: Gazprom Neft PJSC, Gazprom Neft-Sakhalin LLC, Rosneft PJSC and Gazprom Neft Shelf LLC. Experts from these companies evaluated and ranked specific criteria for assessing the strategic sustainability of five offshore oil and gas projects. This assessment was conducted with application of a questionnaire developed by the authors. On the basis of these assessments, the authors made calculations based on methodology which they developed. The authors assessed the sustainability of the projects based on a comprehensive indicator also developed by the authors that takes into account investment, technological, geological, social and environmental sustainability.

The authors believe that the developed approach to strategic sustainability assessment will be useful for Arctic oil and gas projects, and with further improvements, it will provide practical guidance for managers of oil and gas companies.

Recommendations have been provided to develop a system of indicators for assessing the strategic sustainability of offshore oil and gas projects within the following areas of strategic management: finance, technology, logistics and infrastructure, people and processes, HSE, external interactions and global trends.

The authors believe that the development of the Arctic offshore fields should be carried out "step by step", with particular care for the environment and with the understanding that the possible development of (especially large-scale) offshore Arctic hydrocarbon resources is fundamentally inconsistent with the concept of sustainable development. It is often better to develop onshore projects in old oil and gas fields and to increase oil recovery than to start developing new projects in the Arctic. As a result, environmental standards need to be reviewed and tightened. It is very important to determine the level of risk of a given project, the more complex the natural and climatic conditions are and the poorer the infrastructure is, the higher the environmental risks and the more difficult it is to talk 
about sustainability. After all, the authors admit that if there is no certainty about the environmental safety of offshore carbon projects in the Arctic, then such projects should not be implemented.

Author Contributions: Conceptualization, A.C.; methodology, A.C., A.T. and N.K.; writing-original draft preparation, A.C., A.T. and N.K.; writing-review and editing, A.C. All authors have read and agreed to the published version of the manuscript.

Funding: This research received no external funding.

Conflicts of Interest: We declare no conflict of interests.

\section{Appendix A}

Table A1. Results of normalized assessment of the relative importance of Level 1 criteria.

\begin{tabular}{lcccccc}
\hline \multicolumn{1}{c}{ Criteria } & $\begin{array}{c}\text { Investment } \\
\text { Sustainability }\end{array}$ & $\begin{array}{c}\text { Technological } \\
\text { Stability }\end{array}$ & $\begin{array}{c}\text { Geological } \\
\text { Stability }\end{array}$ & $\begin{array}{c}\text { Social } \\
\text { Sustainability }\end{array}$ & $\begin{array}{c}\text { Environmental } \\
\text { Sustainability }\end{array}$ & Amount \\
\hline Investment & 0.15 & 0.10 & 0.15 & 0.22 & 0.29 & 0.90 \\
sustainability & 0.30 & 0.19 & 0.15 & 0.21 & 0.29 & 1.15 \\
Technological stability & 0.45 & 0.58 & 0.44 & 0.29 & 0.29 & 2.05 \\
Sustainability in terms & 0.05 & 0.06 & 0.11 & 0.07 & 0.03 & 0.33 \\
of geology & 0.05 & 0.06 & 0.15 & 0.21 & 0.10 & 0.57 \\
Social sustainability & Environmental & & & & & \\
sustainability & & &
\end{tabular}

Source: calculations by the authors.

Table A2. Results of assessment of relative importance of investment sustainability criteria.

\begin{tabular}{lcccc}
\hline \multicolumn{1}{c}{ Criteria } & Commissioning Time & UTC & EMV & $\begin{array}{c}\text { Expenditure on the Geological } \\
\text { Exploration Program }\end{array}$ \\
\hline Commissioning time & $1 / 1$ & $1 / 3$ & $1 / 4$ & $1 / 2$ \\
UTC (Unit Total Cost) & $3 / 1$ & $1 / 1$ & $1 / 2$ & $1 / 1$ \\
EMV (Expected Monetary Value) & $4 / 1$ & $2 / 1$ & $1 / 1$ & $3 / 1$ \\
Expenditure on the geological & $2 / 1$ & $1 / 1$ & $1 / 3$ & $1 / 1$ \\
exploration program & 10.00 & 4.33 & 2.08 & 5.50 \\
Amount & & & \\
\hline
\end{tabular}

Source: calculations by the authors.

Table A3. Results of assessment of relative importance of technological sustainability criteria.

\begin{tabular}{lccc}
\hline \multicolumn{1}{c}{ Criteria } & $\begin{array}{c}\text { Technological Possibility of } \\
\text { Project Implementation }\end{array}$ & EU and US Sanctions & $\begin{array}{c}\text { Oil and Gas Field } \\
\text { Complexity Category }\end{array}$ \\
\hline Technological possibility of & $1 / 1$ & $1 / 7$ & $1 / 2$ \\
project implementation & $7 / 1$ & $1 / 1$ & $2 / 1$ \\
EU and US sanctions & $2 / 1$ & $\frac{1}{2}$ & $1 / 1$ \\
Oil and gas field complexity & 10.00 & 1.33 & 3.50 \\
category & Amount & & \\
\hline
\end{tabular}


Table A4. Results of the assessment of the relative importance of the geological sustainability criteria.

\begin{tabular}{lcccc}
\hline \multicolumn{1}{c}{ Criteria } & $\begin{array}{c}\text { Potential for } \\
\text { Accumulated } \\
\text { Production }\end{array}$ & $\begin{array}{c}\text { Success } \\
\text { Evaluation }\end{array}$ & $\begin{array}{c}\text { Difference in } \\
\text { Accumulated } \\
\text { Production P10/P50 }\end{array}$ & $\begin{array}{c}\text { Geological } \\
\text { Exploration }\end{array}$ \\
\hline $\begin{array}{l}\text { Potential for accumulated production } \\
\begin{array}{l}\text { Success evaluation P = (Extractable } \\
\text { resources of the entity-minimum } \\
\text { required resource size)/Extractable }\end{array}\end{array} \quad 1 / 1$ & $1 / 2$ & $1 / 1$ & $\frac{1}{2}$ \\
$\begin{array}{l}\text { resources of the entity } \times \text { gCOS } \times 100 \\
\text { Minimization of difference on }\end{array}$ & $2 / 1$ & $1 / 1$ & $1 / 2$ & $1 / 3$ \\
accumulated production P10/P50 & $1 / 1$ & $2 / 1$ & $1 / 1$ & $1 / 3$ \\
Geological exploration & $2 / 1$ & $3 / 1$ & $3 / 1$ & $1 / 1$ \\
Amount & 6.00 & 6.50 & 5.5 & 2.16 \\
\hline
\end{tabular}

Source: calculations by the authors.

Table A5. Results of assessment of relative importance of social sustainability criteria.

\begin{tabular}{lcccc}
\hline \multicolumn{1}{c}{ Criteria } & New Jobs & $\begin{array}{c}\text { Inflow of Highly } \\
\text { Qualified Staff into the } \\
\text { Project from Other } \\
\text { Companies }\end{array}$ & $\begin{array}{c}\text { Growth of } \\
\text { Competencies of } \\
\text { Company Employees } \\
\text { Implementing the } \\
\text { Project }\end{array}$ & $\begin{array}{c}\text { Mechanisms for } \\
\text { Feedback from Public } \\
\text { Organizations and } \\
\text { Regional Management } \\
\text { Structures }\end{array}$ \\
\hline $\begin{array}{l}\text { New jobs } \\
\begin{array}{l}\text { Inflow of highly qualified staff into } \\
\text { the project from other companies }\end{array}\end{array}$ & $1 / 1$ & $1 / 3$ & $1 / 4$ & $1 / 2$ \\
$\begin{array}{l}\text { Growth of competencies of company } \\
\text { employees implementing the project } \\
\begin{array}{l}\text { Mechanisms for feedback from public } \\
\text { organizations and regional }\end{array}\end{array}$ & $4 / 1$ & $1 / 1$ & $1 / 1$ & $1 / 1$ \\
$\begin{array}{l}\text { management structures } \\
\text { Amount }\end{array}$ & $1 / 1$ & $2 / 1$ & $1 / 1$ & $1 / 1$ \\
\hline
\end{tabular}

Source: calculations by the authors.

Table A6. Results of the assessment of the relative importance of environmental sustainability criteria.

\begin{tabular}{|c|c|c|c|c|}
\hline Criteria & $\begin{array}{c}\text { Reliable oil Spill } \\
\text { Response } \\
\text { Technology }\end{array}$ & $\begin{array}{l}\text { Preservation of } \\
\text { Marine Ecosystems } \\
\text { and Biodiversity }\end{array}$ & $\begin{array}{c}\text { Minimization of } \mathrm{CO}_{2} \\
\text { Emissions during } \\
\text { Extraction and } \\
\text { Transportation }\end{array}$ & $\begin{array}{l}\text { Creation of Additional } \\
\text { Insurance Funds of a } \\
\text { Financial Nature }\end{array}$ \\
\hline $\begin{array}{l}\text { Reliable oil spill response } \\
\text { technology }\end{array}$ & $1 / 1$ & $1 / 3$ & $1 / 1$ & $2 / 1$ \\
\hline $\begin{array}{l}\text { Preservation of marine } \\
\text { ecosystems and biodiversity }\end{array}$ & $3 / 1$ & $1 / 1$ & $3 / 1$ & $2 / 1$ \\
\hline $\begin{array}{l}\text { Creation of additional insurance } \\
\text { funds of a financial nature }\end{array}$ & $1 / 2$ & $\frac{1}{2}$ & $2 / 1$ & $1 / 1$ \\
\hline Amount & 5.50 & 2.17 & 7.00 & 5.50 \\
\hline
\end{tabular}

Source: calculations by the authors.

Table A7. Results of a normalized assessment of the relative importance of the investment sustainability criteria.

\begin{tabular}{lccccc}
\hline \multicolumn{1}{c}{ Criteria } & $\begin{array}{c}\text { Commissioning } \\
\text { Time }\end{array}$ & UTC & EMV & $\begin{array}{c}\text { Expenditure on the Geological } \\
\text { Exploration Program }\end{array}$ & Amount \\
\hline Commissioning time & 0.10 & 0.08 & 0.12 & 0.09 & 0.39 \\
UTC (Unit Total Cost) & 0.30 & 0.23 & 0.24 & 0.18 & 0.95 \\
EMV (Expected Monetary Value) & 0.40 & 0.46 & 0.48 & 0.55 & 0.18 \\
$\begin{array}{l}\text { Expenditure on the geological } \\
\text { exploration program }\end{array}$ & 0.20 & 0.23 & 0.16 & 0.77 \\
\hline
\end{tabular}


Table A8. Results of a normalized assessment of the relative importance of technological sustainability criteria.

\begin{tabular}{lcccc}
\hline \multicolumn{1}{c}{ Criteria } & $\begin{array}{c}\text { Technological Possibility } \\
\text { of Project Implementation }\end{array}$ & $\begin{array}{c}\text { EU and US } \\
\text { Sanctions }\end{array}$ & $\begin{array}{c}\text { Oil and Gas Field } \\
\text { Complexity Category }\end{array}$ & Amount \\
\hline $\begin{array}{l}\text { Technological possibility } \\
\text { of project }\end{array}$ & 0.55 & 0.40 & 0.67 & 0.35 \\
$\begin{array}{l}\text { implementation } \\
\text { EU and US sanctions }\end{array}$ & 0.27 & 0.20 & 0.11 & 2.02 \\
$\begin{array}{l}\text { Oil and gas field } \\
\text { complexity category }\end{array}$ & 0.18 & 0.40 & 0.22 & 0.86 \\
\hline
\end{tabular}

Source: calculations by the authors.

Table A9. Results of a normalized assessment of the relative importance of the geological sustainability criteria.

\begin{tabular}{|c|c|c|c|c|c|}
\hline Criteria & $\begin{array}{l}\text { Potential for } \\
\text { Accumulated } \\
\text { Production }\end{array}$ & $\begin{array}{c}\text { Success } \\
\text { Evaluation }\end{array}$ & $\begin{array}{c}\text { Difference in } \\
\text { Accumulated } \\
\text { Production P10/P50 }\end{array}$ & $\begin{array}{c}\text { Geological } \\
\text { Exploration }\end{array}$ & Amount \\
\hline $\begin{array}{l}\text { Potential for accumulated } \\
\text { production }\end{array}$ & 0.17 & 0.08 & 0.18 & 0.23 & 0.66 \\
\hline $\begin{array}{l}\text { Success evaluation } \mathrm{P}=(\text { Extractable } \\
\text { resources of the entity }- \text { minimum } \\
\text { required resource size }) / \text { Extractable } \\
\text { resources of the entity } \times \text { gCOS } \times 100\end{array}$ & 0.33 & 0.15 & 0.09 & 0.15 & 0.73 \\
\hline $\begin{array}{l}\text { Difference in accumulated } \\
\text { production P10/P50 }\end{array}$ & 0.17 & 0.31 & 0.18 & 0.15 & 0.81 \\
\hline Geological exploration & 0.33 & 0.46 & 0.55 & 0.46 & 1.80 \\
\hline
\end{tabular}

Source: calculations by the authors.

Table A10. Results of a normalized assessment of the relative importance of the social sustainability criteria.

\begin{tabular}{lccccc}
\hline \multicolumn{1}{c}{ Criteria } & $\begin{array}{c}\text { New } \\
\text { Jobs }\end{array}$ & $\begin{array}{c}\text { Inflow of Highly } \\
\text { Qualified Staff into } \\
\text { the Project from } \\
\text { Other Companies }\end{array}$ & $\begin{array}{c}\text { Growth of } \\
\text { Competencies of } \\
\text { Company Employees } \\
\text { Implementing the } \\
\text { Project }\end{array}$ & $\begin{array}{c}\text { Mechanisms for } \\
\text { Feedback from Public } \\
\text { Organizations by } \\
\text { Regional Management } \\
\text { Structures }\end{array}$ & Amount \\
\hline $\begin{array}{l}\text { New jobs } \\
\begin{array}{l}\text { Inflow of highly qualified staff } \\
\text { into the project from other } \\
\text { companies }\end{array}\end{array}$ & 0.18 & 0.15 & 0.14 & 0.36 & 0.84 \\
$\begin{array}{l}\text { Growth of competencies of } \\
\text { company employees } \\
\text { implementing the project }\end{array}$ & 0.15 & 0.46 & 0.43 & 0.36 & 0.09 \\
$\begin{array}{l}\text { Mechanisms for feedback from } \\
\text { public organizations by regional } \\
\text { structures }\end{array}$ & 0.09 & 0.15 & 0.14 & 0.18 & 0.57 \\
\hline
\end{tabular}

Source: calculations by the authors.

Table A11. Results of normalized assessment of the relative importance of environmental sustainability criteria.

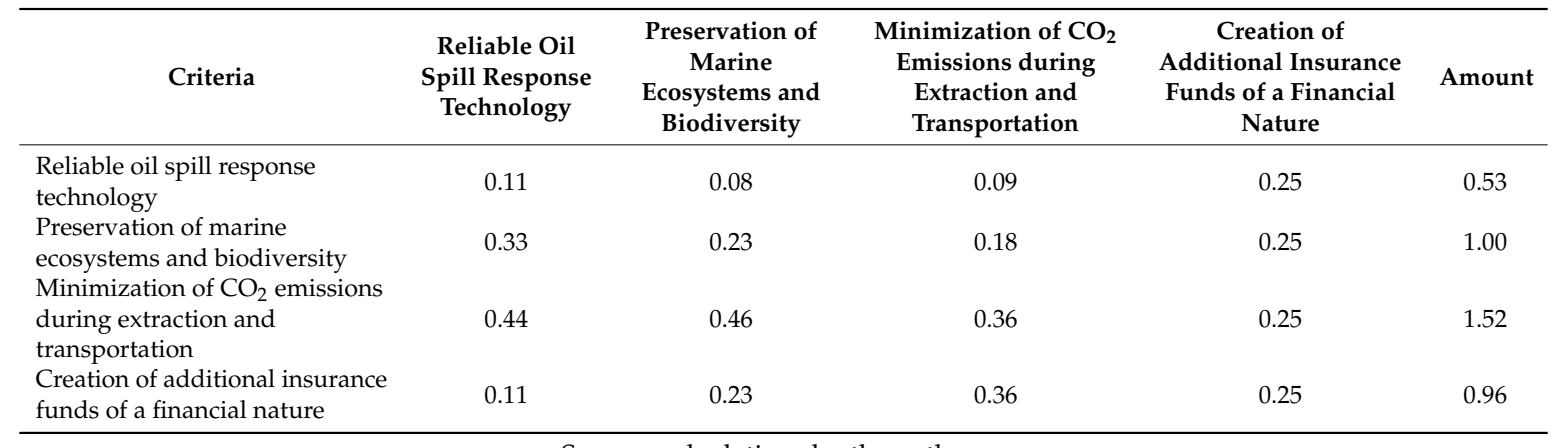




\section{References}

1. Russian News Agency (Tass). Oil Reserves of the Russian Arctic Zone Are Estimated at 7.3 Billion Tons. 2019. Available online: https://tass.ru/ekonomika/7109643 (accessed on 2 August 2020). (In Russian).

2. The Russian Ministry of Energy Official Internet Site. Alexander Novak: $60 \%$ of Recoverable Hydrocarbon Resources in Russia Are Concentrated in the Arctic. 2019. Available online: https://minenergo.gov.ru/node/ 7327 (accessed on 2 August 2020). (In Russian)

3. Russian Federation Strategy for the Development of the Arctic and National Security until 2020 (2013). Available online: http://legalacts.ru/doc/strategija-razvitija-arkticheskoi-zony-rossiiskoi-federatsii-i/ (accessed on 2 August 2020). (In Russian)

4. Cherepovitsyn, A.E.; Lipina, S.A.; Evseeva, O.O. Innovative approach to the development of mineral raw materials of the Arctic zone of the Russian Federation. J. Min. Inst. 2018, 232, 438-444. (In Russian)

5. Litvinenko, V.S.; Tsvetkov, P.S.; Molodtsov, K.V. The Social and Market Mechanism of Sustainable Development of Public Companies in the Mineral Resource Sector. Eurasian Min. 2020, 1, 36-41. Available online: http://rudmet.net/media/articles/Article_EM_01_20_pp.36-41.pdf (accessed on 2 August 2020). [CrossRef]

6. Ilyinsky, A.A.; Tan, S. Strategic Priorities for the Development of the Oil Production Complex when Developing Marginal Fields; Publishing House of the Kola Science Center: Apatity, Russia, 2019; 132p. (In Russian)

7. Afanasyev, R.A.; Barasheva, T.I.; Bogoyavlensky, V.I.; Budagova, I.V.; Vysotskaya, T.A.; Vysotskaya, N.A.; Herashchenko, L.V.; Dmitrievsky, A.N.; Dyachkova, M.A.; Evdokimova, G.P.; et al. Marine Strategy of Russia and Priorities of Arctic Development; Publishing House of the Kola Science Center: Apatity, Russia, 2012; 416p. (In Russian)

8. Litvinenko, V.S. Foreword: Sixty-Year Russian History of Antarctic Sub-Glacial Lake Exploration and Arctic Natural Resource Development. Geochemistry 2020, 1, 1-4. Available online: https://www.sciencedirect.com/ science/article/pii/S0009281920300568 (accessed on 2 August 2020).

9. Ilinova, A.A.; Chanysheva, A.F.; Solovyova, V.M. Arctic oil and gas offshore projects: How to forecast their future. IOP Conf. Ser. Earth Environ. Sci. 2020, 539, 012153. [CrossRef]

10. Chanysheva, A.F.; Ilinova, A.A.; Solovyova, V.M.; Cherepovitsyn, A.E. Long-term forecasts of the oil and gas Arctic shelf development: The existing methodical approaches and assessment of a possibility of their application. IOP Conf. Ser. Earth Environ. Sci. 2019, 302, 012068. [CrossRef]

11. Malyshkov, G.B.; Sinkov, L.S.; Nikolaichuk, L.A. Analysis of Economic Evaluation Methods of Environmental Damage at Calculation of Production Efficiency in Mining Industry. Int. J. App. Eng. Res. 2017, 12, 2551-2554.

12. Ilinova, A.A.; Romasheva, N.V.; Stroykov, G.A. Prospects and social effects of carbon dioxide sequestration and utilization projects. J. Min. Inst. 2020, 244, 493-502. [CrossRef]

13. Bashmakova, E.P.; Gushchina, I.A.; Kondratovich, D.L.; Korchak, E.A.; Ryabova, L.A.; Novikova, N.A.; Polozhentseva, O.A.; Stepanova, E.N.; Toichkina, V.P.; Toropushina, E.E. Social Stability of the Regions of the Russian North and Arctic: Assessment and Ways of Achievement; Publishing House of the Kola Science Center: Apatity, Russia, 2018. (In Russian)

14. Alabyev, V.R.; Kruk, M.N.; Bazhina, T.P.; Semenov, A.S.; Demin, V.I. Economic efficiency of the application of artificial air cooling for normalization of thermal conditions in oil mines. Sci. Iran. 2020, 27, 1606-1615. [CrossRef]

15. Vasilenko, N.; Khaykin, M.; Kirsanova, N.; Lapinskas, A.; Makhova, L. Issues for Development of Economic System for Subsurface Resource Management in Russia through Lens of Economic Process Servitization. Int. J. Energy Econ. Policy 2019, 10, 44-48. Available online: https://www.econjournals.com/index.php/ijeep/ article/view/8303 (accessed on 2 August 2020). [CrossRef]

16. Ilinova, A.A.; Chanysheva, A.F. Algorithm for Assessing the Prospects of Offshore Oil and Gas Projects in the Arctic. Energy Rep. 2020, 6, 504-509. Available online: https://www.sciencedirect.com/science/article/pii/ S235248471931025X?via\%3Dihub (accessed on 2 August 2020). [CrossRef]

17. Ponomarenko, T.V.; Marinina, O.A. Corporate responsibility of mining companies: Mechanisms of interaction with stakeholders in projects implementation. J. Appl. Econ. Sci. 2017, 12, 1826-1838.

18. Kirsanova, N.Y.; Lenkovets, O.M. Influence of railroad industry on social and economic development of Russia. In Proceedings of the 19th International Multidisciplinary Scientific Geoconference, Sofia, Bulgaria, 28 June-7 July 2019; pp. 421-428. [CrossRef] 
19. Ilinova, A.A.; Dmitrieva, D.M. The mechanism of innovative development of the Russian arctic zone. Int. J. Mech. Eng. Technol. 2018, 9, 1439-1451.

20. Cherepovitsyn, A.; Chvileva, T.; Fedoseev, S. Popularization of carbon capture and storage technology in society: Principles and methods. Int. J. Environ. Res. Public Health 2020, 17, 8368. [CrossRef] [PubMed]

21. Romasheva, N.; Ilinova, A. CCS projects: How regulatory framework influences their deployment. Resources 2019, 8, 181. [CrossRef]

22. Pytkin, A.N.; Balandin, D.A. Investment Activities in the Development of the Arctic Region; Publishing house of the Federal State Budgetary Institution of Science of the Institute of Economics of the Ural Branch of the Russian Academy of Sciences: Perm, Russia, 2013; 186p. (In Russian)

23. Bobyleva, A.Z.; Lvova, O.A.; Peganova, O.M.; Teplova, T.V.; Popova, S.S.; Sudas, L.G.; Guliev, I.A.; Zhavoronkova, E.N. State Anticrisismanagement in Oilindustry; Urait Publishing House: Moscow, Russia, 2018; 327p. (In Russian)

24. Mitrova, A.; Grushevenko, E.; Malov, A. Prospects of Russian Oil Production: Life under Sanctions. Rep Skolkovo Found 2018. Available online: https://energy.skolkovo.ru/downloads/documents/SEneC/ research04-ru.pdf (accessed on 2 August 2020). (In Russian)

25. Feoktistova, E.; Kopylova, G.; Ozeryanskaya, M.; Moskvina, M.; Hofmann, N.; Purtova, D. Russian Business and Sustainable Development Goals. Corporate Practices Collection; RSPP: Moscow, Russia, 2018; 200p. Available online: http://media.rspp.ru/document/1/b/2/b24091d44c9660fcf3a9fdad6551b88f.pdf (accessed on 7 November 2020). (In Russian)

26. Aleksandrova, T.N.; Nikolaeva, N.V.; Lvov, V.V.; Romashev, A.O. Ore processing efficiency improvements for precious metals based on process simulations. Miner. Process. Obogashchenie Rud 2019, 2, 8-13. (In Russian) [CrossRef]

27. Lvov, V.; Sishchuk, J.; Chitalov, L. Intensification of Bond ball mill work index test through various methods. In Proceedings of the 17th International Multidisciplinary Scientific Geoconference and Expo SGEM, Sofia, Bulgaria, 29 June-5 July 2017; Volume 17, pp. 857-864. [CrossRef]

28. Teplova, T.V. Investments: Training for Bachelors; Yureit: Moscow, Russia, 2012; 724p. (In Russian)

29. Azriliyan, A.N.; Azriliyan, O.M.; Kalashnikova, E.V.; Kvardakova, O.V. Large Economic Dictionary: 26,500 Terms, 7th ed.; Azriliyan, A.N., Ed.; New Economy In-t of: Moscow, Russia, 2007; 1472p. (In Russian)

30. Lopatnikov, L.I. Brief Economic and Mathematical Dictionary; Science: Moscow, Russia, 2009; 520p. (In Russian)

31. Altshuler, I.G. Strategic Management Based on Marketing Analysis. Tools, Problems, Situations; Vershina: Moscow, Russia, 2006; 232p. (In Russian)

32. Manitskaya, L.N. Adaptive Management of Strategic Sustainability of the Enterprise; Business in Law: Perm, Russia, 2010; 255p. (In Russian)

33. Brundtland, G. World Commission on Environment and Development. Our Common Future. In Proceedings of the United Nations General Assembly A/42/427, Brussels, Belgium, 5 May 1987.

34. Giddings, B.; Hopwood, B.; O’Brien, G. Environment, economy and society: Fitting them together into sustainable development. Sustain. Dev. 2002, 10, 187-196. [CrossRef]

35. Meadows, D.; Randers, J.; Meadows, D. Limits to Growth: The 30-Year Update; Chelsea Green Publishing: Vermont, VT, USA, 2004.

36. Daly, H.E. Beyond Growth: The Economics of Sustain. Development; Beacon Press: Boston, MA, USA, 1996.

37. Ehrlich, P.R.; Ehrlich, A.H. The Population Explosion; Simon and Schuster: New York, NY, USA, 1990.

38. Meadows, D.H.; Meadows, G.; Randers, G.J.; Behrens, W.W. The Limits to Growth; Universe Books: New York, NY, USA, 1972.

39. Gray, R.; Milne, M.J. Sustainability reporting: Who's kidding whom? Chart. Account. J. N. Z. 2002, 81, 66-70.

40. Holling, C.S. Resilience and stability of ecological systems. Annu. Rev. Ecol. Syst. 1973, 4, 1-23. [CrossRef]

41. Rockström, J.; Steffen, W.L.; Noone, K.; Persson, Å.; Chapin, F.S., III; Lambin, E.; Lenton, T.M.; Scheffer, M.; Folke, C.; Schellnhuber, H.; et al. Planetary boundaries: Exploring the safe operating space for humanity. Ecol. Soc. 2009, 14, 1-33.

42. Tcvetkov, P.; Cherepovitsyn, A.; Fedoseev, S. The changing role of $\mathrm{CO}_{2}$ in the transition to a circular economy: Review of carbon sequestration projects. Sustainability 2019, 11, 5834. [CrossRef]

43. Vasilev, Y.; Vasileva, P.; Tsvetkova, A. International review of public perception of CCS technologies. In Proceedings of the International Multidisciplinary Scientific GeoConference SGEM, Sofia, Bulgaria, 28 June-7 July 2019; Volume 19, pp. 415-422. [CrossRef] 
44. Enríquez-de-Salamanca, Á. Stakeholders' manipulation of Environmental Impact Assessment. Environ. Impact Assess. 2018, 68, 10-18. [CrossRef]

45. Dale, B.; Bay-Larsen, I.; Skorstad, B. The Will to Drill-Mining in Arctic Communities; Springer: Cham, Germany, 2018.

46. Oskal, A.; Turi, J.M.; Mathiesen, S.D.; Burgess, P. Arctic Council's Sustainable Development Working Group, 2009. In Ealát. Reindeer Herders' Voice: Reindeer Herding, Traditional Knowledge and Adaptation to Climate Change and Loss of Grazing Land. Available online: https://oaarchive.arctic-council.org/handle/11374/47 (accessed on 2 August 2020).

47. Herrmann, T.M.; Sandström, P.; Granqvist, K.; D'Astous, N.; Vannar, J.; Asselin, H.; Saganash, N.; Mameamskum, J.; Guanish, G.; Loon, J.-B.; et al. Effects of mining on reindeer/caribou populations and indigenous livelihoods: Community-based monitoring by Sami reindeer herders in Sweden and First Nations in Canada. Polar J. 2014, 4, 28-51. [CrossRef]

48. Kumpula, T.; Pajunen, A.; Kaarlejärvi, E.; Forbes, B.C.; Stammler, F. Land use and land cover change in Arctic Russia: Ecological and social implications of industrial development. Glob. Environ. Chang. 2011, 21, 550-562. [CrossRef]

49. Cuthill, M. Strengthening the 'social' in sustainable development: Developing a conceptual framework for social sustainability in a rapid urban growth region in Australia. Sustain. Dev. 2010, 18, 362-373. [CrossRef]

50. Colantonio, A. Traditional and emerging prospects in social sustainability. In Measuring Social Sustainability: Best Practice from Urban Renewal in the EU; 2008/02: EIBURS Working Paper Series; Oxford Institute for Sustainable Development (OISD): Oxford, UK, 2008.

51. Hanna, K.; McGuigan, E.; Noble, B.; Parkins, J. An analysis of the state of impact assessment research for low carbon power production: Building a better understanding of information and knowledge gaps. Energy Res. Soc. Sci. 2019, 50, 116-121. [CrossRef]

52. Khan, I. Critiquing social impact assessments: Ornamentation or reality in the Bangladeshi electricity infrastructure sector? Energy Res. Soc. Sci. 2020, 60, 101339. [CrossRef]

53. World Bank (WB). Legal Framework for Renewable Energy. In Regulatory Indicators for Sustainable Energy, 2017. Available online: https://rise.worldbank.org/indicators (accessed on 20 January 2020).

54. Vanclay, F. Reflections on Social Impact Assessment in the 21st century. Impact Assess. Proj. Appraisal 2019, 38, 1-6. [CrossRef]

55. Batel, S.; Devine-Wright, P.; Tangeland, T. Social acceptance of low carbon energy and associated infrastructures: A critical discussion. Energ. Policy 2013, 58, 1-5. [CrossRef]

56. Wolfsink, M. The research agenda on social acceptance of distributed generation in smart grids: Renewable as common pool resources. Renew. Sust. Energ. Rev. 2012, 16, 822-835. [CrossRef]

57. Dempsey, N.; Bramley, G.; Power, S.; Brown, C. The Social Dimension of Sustainable Development: Defining Urban Social Sustainability. Sustain. Dev. 2011, 19, 289-300. [CrossRef]

58. Campbell, S. Green cities, growing cities, just cities? J. Am. Plan. Assoc. 1996, 62, 296-312. [CrossRef]

59. Jenkins, K.; McCauley, D.; Heffron, R.; Stephan, H.; Rehner, R. Energy justice: A conceptual review. Energy Res. Soc. Sci. 2016, 11, 174-182. [CrossRef]

60. Heffron, R.J.; McCauley, D. What is the "Just Transition"? Geoforum 2018, 88, 74-77. [CrossRef]

61. Groves, C.; Munday, M.; Yakovleva, N. Fighting the pipe: Neoliberal governance and barriers to effective community participation in energy infrastructure planning. Environ. Plan. C Gov. Policy 2013, 31, 340-356. [CrossRef]

62. Coelho, V.; Favareto, A. Participatory governance and development: In search of a causal nexus. Geogr. Compass 2011, 5, 641-654. [CrossRef]

63. Linnerooth-Bayer, J. Fair strategies for siting hazardous waste facilities. In Managing Conflict in Facility Siting; Lesbirel, S.H., Shaw, D., Eds.; Edward Elgar Publishing: Cheltenham, UK, 2005.

64. VanSchie, R.; Haider, W. Indigenous-based approaches to territorial conservation: A case study of the Algonquin Nation of Wolf Lake. Conserv. Soc. 2015, 13, 72.

65. Ross, S.G. From consultation to consent: A comparative analysis of Arctic states. In Arctic Summer College Yearbook; O’Donnell, B., Gruenig, M., Riedel, A., Eds.; Springer: Cham, Germany, 2018; pp. 9-20.

66. Kearney, J.; Berkes, F.; Charles, A.; Pinkerton, E.; Wiber, M. The role of participatory governance and community-based management in integrated coastal and ocean management in Canada. Coast. Manag. 2007, 35, 79-104. [CrossRef] 
67. Sabanchiev, N.A. Theoretical and Methodological Basis of Organizational Support of Strategic Stability; Dissertation of the Candidate of Economic Sciences; State University of Management: Moscow, Russia, 2009; 136p. (In Russian)

68. Galitskaya, Y. Evaluation of the Strategic Stability of Enterprises (on the Example of the Krasnodar Region Wine Industry); Dissertation of the Candidate of Economic Sciences; Kuban State Technological University: Krasnodar, Russia, 2008; 123p. (In Russian)

69. Dudin, M.N. Ensuring the Strategic Stability of Business Structures in Conditions of Innovative Development; Doctoral Dissertation in Economics; Russian Academy of Entrepreneurship: Moscow, Russia, 2013; 375p. (In Russian)

70. Kucheryavy, A.V. Competitiveness and Strategic Stability of Industrial Enterprise: Dissertation of the Candidate of Economic Sciences; Russian Academy of Entrepreneurship: Moscow, Russia, 2003; 125p. (In Russian)

71. Baranenko, S.P.; Shemetov, V.V. Strategic Stability of the Enterprise; Centerpolygraph: Moscow, Russia, 2004; 493p. (In Russian)

72. Terentyeva, T.V. Methodological Basis for Sustainable Development of Fishery Business Structures; Doctoral Dissertation in Economics; Vladivostok State University of Economics and Service: Vladivostok, Russia, 2014; 304p. (In Russian)

73. Rychykhina, N.S. Restructuring of an Enterprise as an Instrument of Economic Stabilization in Conditions of Market Instability; Dissertation of the Candidate of Economic Sciences; Ivanovo State University of Chemical Technology: Ivanovo, Russia, 2007; 126p. (In Russian)

74. Alonzi, A. What is Project Sustainability? Available online: https://proposalsforngos.com/what-is-projectsustainability/ (accessed on 30 August 2020).

75. Baumgartner, R.J.; Ebner, D. Corporate Sustainability Strategies: Sustainability Profiles and Maturity Levels. Available online: https://www.researchgate.net/publication/227650865_Corporate_Sustainability_Strategies_ Sustainability_Profiles_and_Maturity_Levels (accessed on 30 August 2020).

76. Baumgartner, R.J. Strategic Perspectives of Corporate Sustainability Management to Develop a Sustainable Organization. Available online: https://www.researchgate.net/publication/304358128_ Strategic_perspectives_of_corporate_sustainability_management_to_develop_a_sustainable_organization (accessed on 30 August 2020).

77. Martens, M.L.; Carvalho, M.M. Key Factors of Sustainability in Project Management Context: A Survey Exploring the Project Managers' Perspective. 2017. Available online: https://www.sciencedirect.com/science/ article/abs/pii/S0263786316300163 (accessed on 30 August 2020).

78. Tharp, J. Project Management and Global Sustainability. In Proceedings of the PMI ${ }^{\circledR}$ Global Congress 2012-EMEA, Marseilles, France. Available online: https://www.pmi.org/learning/library/projectmanagement-global-sustainability-6393 (accessed on 5 December 2020).

79. Berkman, P.A.; Vylegzhanin, A.N.; Young, O.R. Legislative Fundamentals of Arctic Policies of Foreign States and of the European Union (Selected Provisions). In Baseline of Russian Arctic Laws; Springer Polar Sciences; Springer: Cham, Switzerland, 2019. Available online: https://link.springer.com/chapter/10.1007/978-3-03006262-0_4\#citeas (accessed on 7 November 2020). [CrossRef]

80. Komendantova, N.; Patt, A.; Barras, L.; Battaglini, A. Perception of risks in renewable energy projects: The case of concentrated solar power in North Africa. Energy Policy 2012, 40, 103-109. [CrossRef]

81. Ondraczek, J.; Komendantova, N.; Patt, A. WACC the Dog: The effect of financing costs on the levelized cost of solar PV power. Renew. Energy 2015, 75, 888-898. [CrossRef]

82. Askar, M.M.; Gab-Allah, A.A. Problems Facing Parties Involved in Build, Operate, and Transport Projects in Egypt. J. Manag. Eng. 2002, 18, 173-178. [CrossRef]

83. Seneviratne, P.N.; Ranasinghe, M. Transportation Infrastructure Financing: Evaluation of Alternatives. J. Infrastruct. Syst. 1997, 3, 111-118. [CrossRef]

84. Coulson, A. Value for money in PFI proposals: A commentary on the UK Treasury Guidelines for Public Sector Comparators. Public Adm. 2008, 86, 483-498. [CrossRef]

85. Tiong, R.L.K. CFSs in Competitive Tendering and Negotiation Model for BOT Projects. ASCE J. Constr. Eng. Manag. 1996, 122, 205-211. [CrossRef]

86. Akintoye, A.; Beck, M.; Hardcastle, C.; Chinyio, E.; Asenova, D. Framework for Risk Assessment and Management of Private Finance Initiative Projects; Glasgow Caledonian University: Glasgow, Scotland, 2001; ISBN 1903664285. 
87. Vining, A.R.; Boardman, A.E. Public-Private Partnerships: Eight Rules for Governments. Public Works Manag. Policy 2008, 13, 149-161. [CrossRef]

88. Mabro, R. Oil in the 21st Century: Issues, Challenges, and Opportunities; Oxford University Press: Oxford, UK, 2006; 368p.

89. Bull, B.; McNeill, D. Development issues in Global Governance. Public Private Partnerships and Development issues in Global Governance. Public Private Partnerships and Market Multilateralism; Routledge: New York, NY, USA, 2007.

90. Komendantova, N.; Voccciante, M.; Battaglini, A. Can the Best Grid Process Improve Stakeholder Involvement in Electricity Transmission Projects? Energies 2015, 8, 9407-9433. [CrossRef]

91. Koivurova, T.; Lesser, P.; Bickford, S.; Kankaanpää, P.; Nenasheva, M. Environmental Impact Assessment in the Arctic: A Guide to Best Practice; Edward Elgar Publishing: Cheltenham, UK, 2016.

92. Voronina, E.P. Risks and Risk Management in Arctic Shelf Oil and Gas Development Projects. Sci. Works Free Econ. Soc. Russia 2014, 182, 190-197. (In Russian)

93. Tsukerman, V.; Fadeev, A.; Kozlov, A. Algorithm for Implementing the Import Substitution Strategy When Exploiting Hydrocarbons on the Arctic Shelf of the Russian Federation. IOP Conf. Ser. Earth Environ. Sci. 2019, 302, 012111. Available online: https://iopscience.iop.org/article/10.1088/1755-1315/302/1/012111 (accessed on 2 August 2020). [CrossRef]

94. Fadeev, A.M.; Cherepovitsyn, A.E.; Larichkin, F.D. Strategic Management of the Oil and Gas Complex in the Arctic: A Monograph; Publishing House of the Kola Science Center: Apatity, Russia, 2019; 289p. (In Russian)

95. World Energy Outlook 2020. Part of World Energy Outlook. Flagship Report-October 2020. Available online: https://www.iea.org/reports/world-energy-outlook-2020?utm_campaign=IEA\% 20newsletters\&utm_source=SendGrid\&utm_medium=Email (accessed on 7 November 2020).

96. Statistical Review of World Energy2020|69th Edition. Available online: https://www.bp.com/content/dam/ bp/business-sites/en/global/corporate/pdfs/energy-economics/statistical-review/bp-stats-review-2020-fullreport.pdf (accessed on 7 November 2020).

97. Ambrose, J. Global Oil Demand may have Passed Peak, Says BP Energy Report. The Guardian. 14 September 2020. Available online: https://www.theguardian.com/business/2020/sep/14/global-oil-demand-may-havepassed-peak-says-bp-energy-report (accessed on 7 November 2020).

98. Molchanov, V.P.; Akimov, V.A.; Sokolov, Y.I. Risks of Emergency Situations in the Arctic Zone of the Russian Federation; All-Russian Research Institute for Civil Defense and Emergencies of the Ministry of Emergency Situations of Russia: Moscow, Russia, 2011; 300p. (In Russian)

99. Kruk, M.; Semenov, A.; Cherepovitsyn, A.; Nikulina, A. Environmental and Economic Damage from the Development of Oil and Gas Fields in the Arctic Shelf of the Russian Federation. Europ. Res. Stud. J. 2018, 21, 423-433. Available online: https://www.ersj.eu/journal/1269/download (accessed on 2 August 2020).

100. Savard, C.; Nikulina, A.; Mécemmène, C.; Mokhova, E. The Electrification of Ships Using the Northern Sea Route: An Approach. J. Open Innov. Technol. Mark. Complex. 2020, 6, 13. [CrossRef]

101. Petrovsky, A. Decision-Making Theory; Academia Publishing Centre: Moscow, Russia, 2009. (In Russian)

102. Keeney, R.L.; Raiffa, H. Decision-Making with Many Criteria: Preferences and Substitutions; Radio and Communication: Moscow, Russia, 1981; 560p. (In Russian)

103. Keeney, R.L.; Raiffa, H. Decisions with Multiple Objectives; Cambridge University Press: Cambridge, UK, 1993; ISBN 0-521-44185-4.

104. Zadeh, L.A. The Concept of a Linguistic Variable and Its Application to Approximate Decision Making; Mir: Moscow, Russia, 1976; 166p. (In Russian)

105. Zadeh, L. From computing with numbers to computing with words-From manipulation of measurements to manipulation of perceptions. Int. J. Appl. Math Comput. Sci. 2002, 12, 307-324.

106. Roy, B. Multicriterial Methodology for Decision Aiding; Chapter 1-2; Kluwer: Dordrecht, The Netherlands, 1996.

107. David, A.; Damart, S. Bernard Roy et l'Aide Multicritère à la Décision. Management Constructeurs Revue Française Gestion 2011, 37, 214. [CrossRef]

108. Larichev, O.I. Decision-Making Theory and Methods, and the Chronicle of Events in Magic Countries: Textbook; Logos: Moscow, Russia, 2002; pp. 88-110. (In Russian)

109. Larichev, O.I.; Olson, D.L. Multiple Criteria Analysis in Strategic Sitting Problems; Kluwer Academmic Publishers: Boston, MA, USA, 2001. 
110. Doran, G.T. There's a S.M.A.R.T. way to write management's goals and objectives. Manag. Rev. 1981, 70, 35-36.

111. Winterfeldt, D.; Edwards, W. Decision Analysis and Behavioral Research; Cambridge University Press: Cambridge, UK, 1986.

112. Saaty, T.L. Decision Making with the Analytic Hierarchy Process. Int. J. Serv. Sci. 2008, 1, 83-98. Available online: https://web.archive.org/web/20170918192816/; http://www.colorado.edu/geography/leyk/ geog_5113/readings/saaty_2008.pdf (accessed on 7 November 2020). [CrossRef]

113. Saati, T.L. Decision Making on Dependencies and Feedback. Analytical Networks; Lenand: Moscow, Russia, 2015; 360p. (In Russian)

Publisher's Note: MDPI stays neutral with regard to jurisdictional claims in published maps and institutional affiliations.

(C) 2020 by the authors. Licensee MDPI, Basel, Switzerland. This article is an open access article distributed under the terms and conditions of the Creative Commons Attribution (CC BY) license (http://creativecommons.org/licenses/by/4.0/). 